\title{
Marine mine tailings disposal at Lillebukt, Stjernsundet, North Norway: distribution, sedimentary processes and depositional impacts
}

\author{
Reidulv Bøe', Roar Sandøy², Nicole J. Baeten', Aivo Lepland', Valérie K. Bellec', \\ Shyam Chand', Oddvar Longva', Martin Klug', Liv Plassen' \& Jasmin Schønenberger' \\ ${ }^{1}$ Geological Survey of Norway, P.O. Box 6315 Torgarden, N-7491 Trondheim, Norway. \\ ${ }^{2}$ Sibelco Nordic AS, P.O. Box 45, N-1309 Rud, Norway. \\ E-mail corresponding author (ReidulvBøe): reidulv.boe@ngu.no
}

\begin{abstract}
Sibelco Nordic's mine on Stjernøya, North Norway, disposes mine tailings into the fjord Stjernsundet. The tailings, discharged at the shoreline in the bay of Lillebukt, comprise c. $85 \%$ fine silt to medium-grained sand $(0.01-0.5 \mathrm{~mm})$. Upon discharge of the mine tailings into the fjord, they are redistributed by slides and density currents along major channels with pronounced levees. Multibeam echosounder data show sand waves in the channels, while seabed samples and cores document sand ripples and layers of mud between the sand layers. Mud accumulates outside of the channels on the seabed in Lillebukt and as a thin veneer along the shores to the east and west. The bathymetry data show partly buried slide escarpments and slide deposits, while smaller slide scars are evident in the levees. Three slide events in the tailings are documented of which the most recent occurred $9^{\text {th }}$ October 2017. Comparison of bathymetry data collected in 2016 and 2018 show changes in bathymetry in the channels of $\pm 3 \mathrm{~m}$. Slides are partly initiated along fine-grained layers and caused by hypersedimentation. From $60 \mathrm{~m}$ depth, one single channel continues down to $100 \mathrm{~m}$, where the sediment transport is along a gully in the steep $\left(45^{\circ}\right)$ bedrock slope down to c. $400 \mathrm{~m}$ depth. A sand-dominated submarine fan has accumulated at the foot of the slope, extending to c. $463 \mathrm{~m}$ depth. Bathymetric data, seismic data and core analysis show that the fan has a radius of up to $1500 \mathrm{~m}$ and covers an area of c. $1.5 \mathrm{~km}^{2}$. Comparison of bathymetry data collected in 1998 and 2016 shows that a large part of the tailings disposed of in that 18 -year period (4 million tons) have accumulated on the submarine fan.
\end{abstract}

Keywords: Submarine tailings placement, Submarine slide, Submarine fan, Seabed morphology, Sedimentary environment, Environmental impact

Received 5. June 2018 / Accepted 16. October 2018 / Published online 5. December 2018

\section{Introduction}

Environmentally sound mining operations require safe and economical storage of mine residues with negligible public health and safety risks and minimal social and environmental impacts (Vogt, 2013; Ramirez-Llodra et al., 2015). In Norway, several mining operations face waste management challenges because of large quantities of tailings, and because sites lie amongst steep and rugged terrain situated close to highly productive fjords. Many mines place their tailings at the seafloor of fjords as submarine tailing placements (STPs). While such practice is not common worldwide, STPs are common in Norway with 18 sites of which 7 were active in 2015 (Ramirez-Llodra et al., 2015).

Major impacts from STPs may include 1) hypersedimentation, 2) sediment plumes and turbidity, 3) resuspension, upwelling and slope failure, 4) changes in organic content, grain size and angularity, 5) metal toxicity, and 6) process chemicals (Ramirez-Llodra et al., 2015). Only the first four are relevant for Lillebukt and Stjernsundet (Fig. 1) as toxic metals are not mined, and process chemicals are not used.

Bøe, R., Sandøy, R., Baeten, N.J., Lepland, A., Bellec, V.K., Chand, S., Longva, O., Klug, M., Plassen, L. \& Schønenberger, J. 2018: Marine mine tailings disposal at Lillebukt, Stjernsundet, North Norway: distribution, sedimentary processes and depositional impacts. Norwegian Journal of Geology 98 , 461-482. https://dx.doi.org/10.17850/njg98-3-08. 


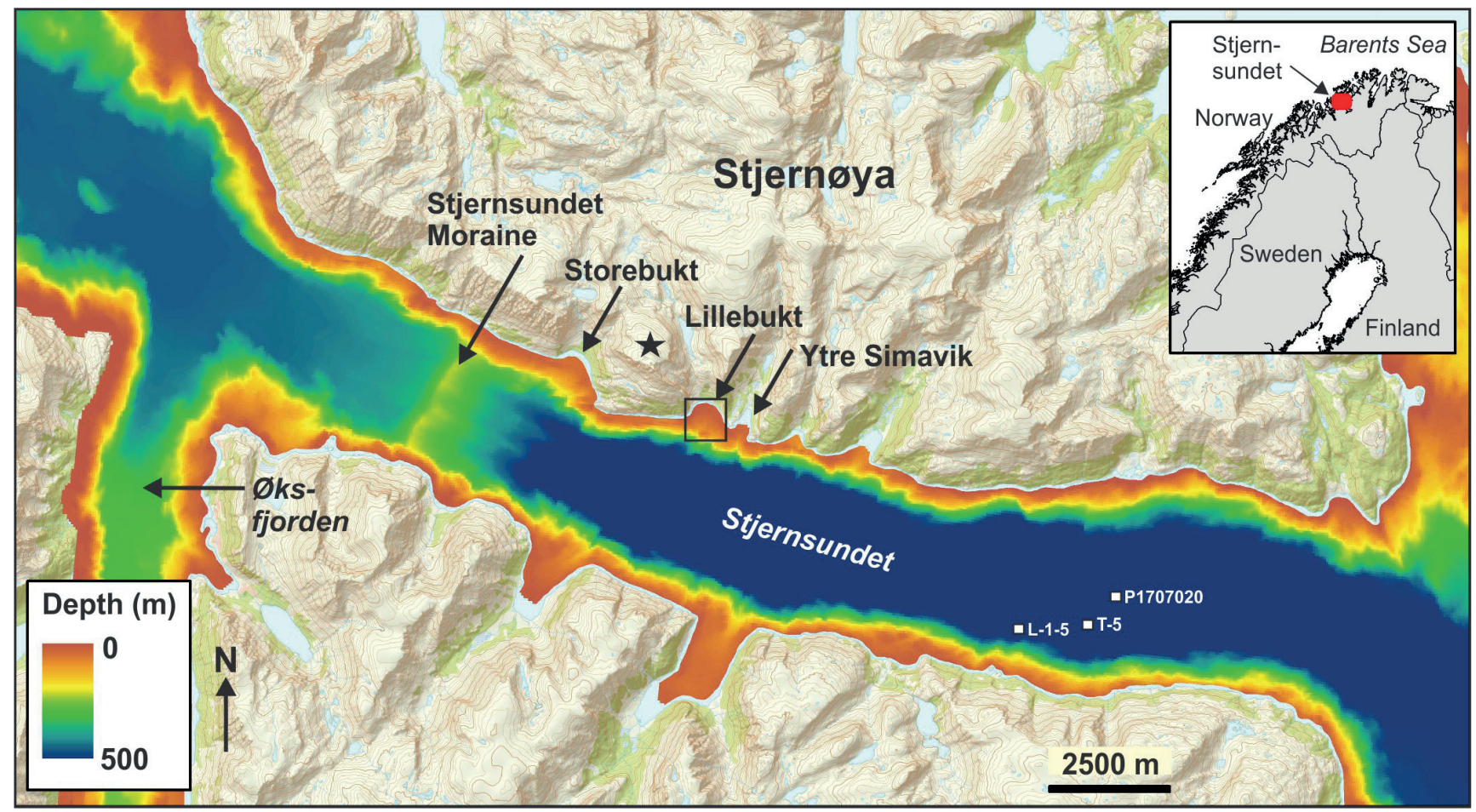

Figure 1. Bathymetric map of Stjernsundet and location of study area. The location of cores L-1-5, T-5 and P1707020 mentioned in the text but located outside of the main study are shown. Black asterix shows location of present mine and black rectangle location of Fig. 5 in Lillebukt.

Ramirez-Llodra et al. (2015) define three different types of tailings disposal in the sea: coastal shallowwater disposal, submarine tailing disposal, and deep-sea tailing placement. The STP in Lillebukt-Stjernsundet is intermediate between the first two, in which the tailings are disposed near the water surface in shallow coastal water in the euphotic zone (Fig. 2; e.g., Franks et al., 2011). The discharge creates slides and gravity flows that deposit the tailings down below $400 \mathrm{~m}$ water depth in Stjernsundet (Ellis et al., 1995; Kvassnes \& Iversen, 2013; Ramirez-Llodra et al., 2015).

The nepheline syenite mined by Sibelco Nordic AS on Stjernøya (Fig. 1) is a quartz-free aluminium silicate rock, giving a processed feldspar-nepheline concentrate consisting primarily of the minerals nepheline, microcline and albite (see below). Because of its low melting point and the high alumina content, nepheline syenite is used as a glass phase promoter, a ceramic flux, and also as a functional filler in paint, plastic, etc. In Lillebukt, the nepheline syenite is crushed, dried, milled, sieved and processed by dry magnetic separation without added substances.

Deposition of tailings started in 1961. The current environmental permit allows a discharge of 300,000 tonnes per year, but deposition has generally been lower (e.g., 213,665 tonnes in 2013; Ramirez-Llodra et al., 2015). Several studies have been carried out to monitor the influence on the marine environment of the tailings disposal (Berge et al., 1993; Trannum \& Vögele,
2001; Larsen et al., 2004; Dahl-Hansen et al., 2012). The previous investigations mainly focused on the influence of tailings on the marine life in the coastal zone based on video observations and seabed sampling but also samples from the deep fjord bottom in Stjernsundet have been studied.

In this study, for the first time, a combination of geophysical, geological and geochemical methods has been used to map the distribution of submarine tailings in Lillebukt and Stjernsundet. Based on new multibeam echosounder data, subbottom profiling, seabed sampling, and sedimentological, geochemical and mineralogical analysis of the samples we interpret the sedimentary processes that redistribute the mine tailings from the tailings outlet to the seabed in Lillebukt and farther into the deep Stjernsundet. We also calculate disposed tailing volumes using time lapse bathymetry.

\section{Bathymetry and oceanography}

Stjernsundet is a 3-4 km-wide fjord between the island of Stjernøya, in the north, and the Norwegian mainland, to the south. A pronounced moraine ridge with water depths of around $200 \mathrm{~m}$ and relative height of around $250 \mathrm{~m}$ crosses Stjernsundet c. $5 \mathrm{~km}$ west of Lillebukt (Figs. 1 \& 3). We name this moraine Stjernsundet Moraine. Westwards of the moraine, depth increases 


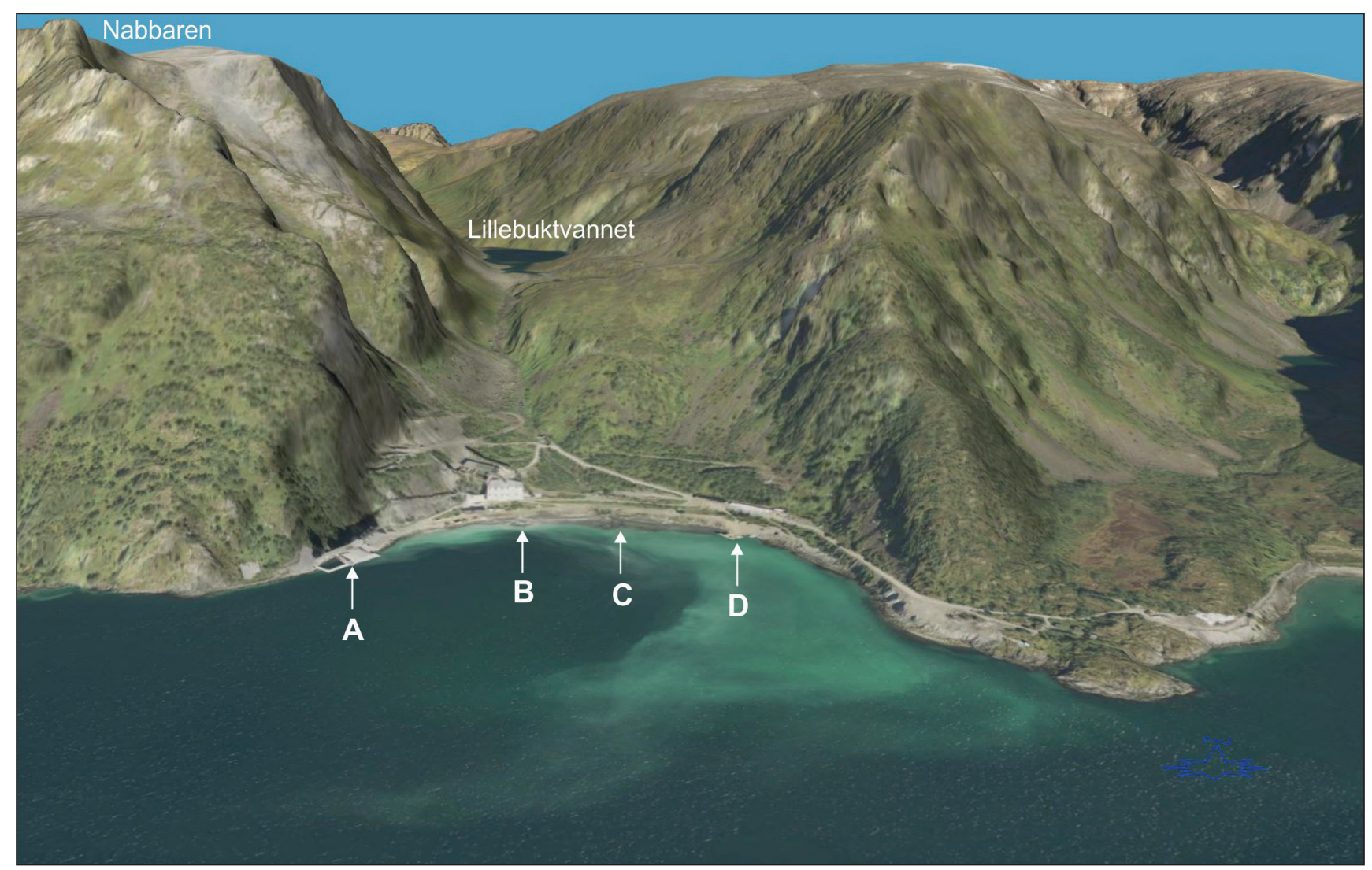

Figure 2. Norkart Virtual Globe 3D view of Lillebukt and surrounding areas showing Sibelco's facilities. A - shipping quay, B-tailings outlet outside administration building/processing plant, $C$ - river outlet, $D$ - passenger quay. Notice light coloured, fine-grained tailings in the surface waters being transported eastwards from the main outlet due to contemporary wave and current action (www.norgei3d.no).

rapidly to $350 \mathrm{~m}$ and then more gradually to around 400 $\mathrm{m}$ at the entrance to Stjernsundet. Southeastwards, depth increases to more than $470 \mathrm{~m}$ in several local depressions at the foot of the ridge and to almost $470 \mathrm{~m}$ in a trench along the southern margin of Stjernsundet, south of Lillebukt. The deepest part of Stjernsundet, with depths more than $480 \mathrm{~m}$, occurs $c .5 \mathrm{~km}$ farther southeast. The fjord sides are steep with slopes of 25-55 degrees.

The main ocean currents outside North Norway are the Norwegian Coastal Current (NCC) and the Norwegian Atlantic Current (NWAC) (Ingvaldsen et al., 2004; Skarđhamar \& Svendsen, 2005; Asplin et al., 2006). The NWAC, which constitutes the main part of the North Atlantic Current (NAC), travels along the continental slope northeastwards to Tromsøflaket, where it splits into one branch running northwards to Spitsbergen and one eastwards into the Barents Sea. The NCC follows the coast from the southwest before turning eastwards into the Barents Sea. It is assumed that the water masses in Stjernsundet are influenced by the NCC as well as by tidal and wind-generated currents.

\section{Geological setting}

Stjernøya and the mainland to the south of Stjernsundet are dominated by gabbro, amphibolite, olivine-rich rocks, pyroxenite, carbonate-rich mica schist and mica gneiss (Heier, 1961; Oosterom, 1963). The Nabbaren Nepheline Syenite (NNS) mined by Sibelco is part of the Lillebukt Alkaline Complex (LAC) (Robins, 1980) of the Seiland Igneous Province (SIP), Norwegian Caledonides (Robins \& Often, 1996; Roberts et al., 2006; Pastore et al., 2016). The SIP comprises gabbroic plutons, high-K calcalkaline intrusions, ultramafic complexes, alkaline rocks, carbonatites and mafic dyke swarms (Robins \& Gardner, 1975; Li, 2013).

The LAC is dominated by hornblende clinopyroxenite, alkali syenites, nepheline syenites and carbonatites (Robins \& Often, 1996). The NNS is the largest nepheline syenite body of the LAC. It is a coarse-grained nepheline syenite lens $1700 \mathrm{~m}$ long and up to $300 \mathrm{~m}$ wide, characterised by high concentration of alkalis, $\mathrm{Ba}$ and Sr, and depletion of REE, Y, Nb, Sc, Zr, U, and Th (Heier \& Taylor, 1962; Heier, 1964, 1966; Geis, 1979). It is dominated by $\mathrm{K}$-rich perthitic alkali feldspar (56\%) 


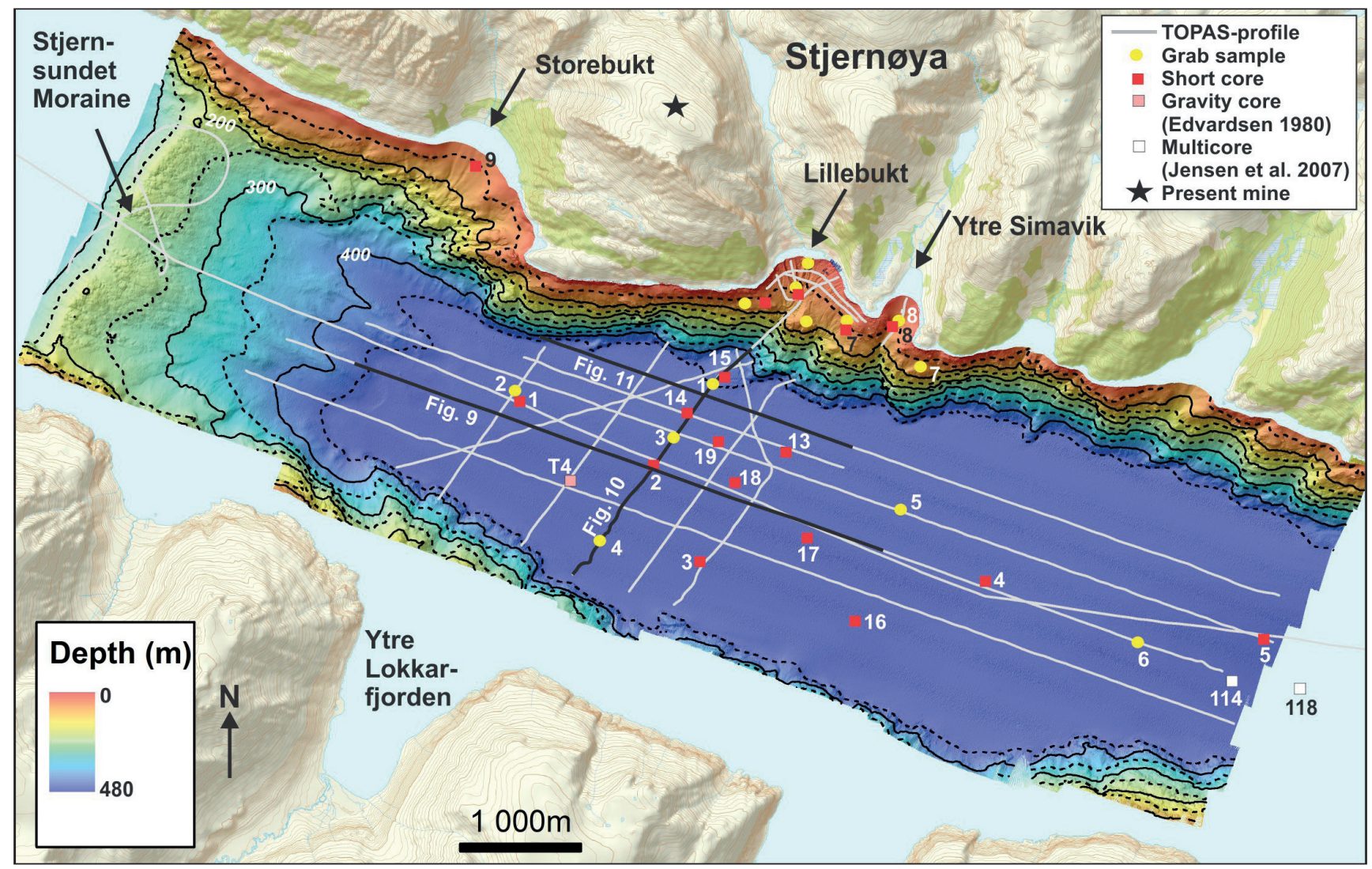

Figure 3. Shaded relief multibeam bathymetry (2016 EM2040 data) with $50 \mathrm{~m}$ depth contours of the study area in Stjernsundet showing the location of the TOPAS profiles and sampling stations. Only the last figures in grab and core numbers are shown (see Table 2 for complete numbers). Grab and core locations without numbers are shown in Figs. 5 \& 7.

and nepheline (34\%), with minor to trace amounts of biotite, hornblende, Ca-rich pyroxene, sodalite, calcite, sphene, magnetite, ilmenite, hercynite, apatite, corundum and zircon (Geis, 1979; Robins \& Often, 1996; Li, 2013). Although transitional types occur, Geis (1979) separated between two different nepheline syenite types of the NNS; the biotite type, and the hornblende-pyroxene type, defined by the most dominant mafic minerals.

The NNS is, like most rocks of the LAC, cut by several generations of mafic dykes from centimetres to metres in width (Ramsay \& Sturt, 1970; Robins \& Takla, 1979). Later hydrothermal and tectonic events have introduced minerals like zeolite (natrolite and thomsonite), stronalsite-banalsite solid-solution minerals, prehnite, palygorskite and kaolin (Holdridge, 1962; Salter \& Appleyard, 1974; Geis, 1979; Li, 2013).

The bedrock in Stjernsundet is covered by Quaternary sediments deposited during and after the last glaciation (e.g., Ottesen et al., 2005, 2008). The pronounced, more than $200 \mathrm{~m}$-high Stjernsundet Moraine crossing Stjernsundet in its western part can probably be correlated with the outer Porsangerfjord moraine (Sollid et al., 1973; Olsen, 1998), which was deposited at a glacier margin approximately 15,000 years ago. MAREANO (www.mareano.no) has documented living Lophelia reefs on the Stjernsundet Moraine. Unpublished seismic data show that the fjord basin to the east of the ridge has a succession of till at the base, overlain by layered glacimarine sediments and with Holocene mud at the top.

\section{Processing of the Nabbaren nepheline syenite}

The nepheline syenite is crushed, dried, sieved and processed by dry magnetic separation without added chemicals, followed by sieving and milling to produce the nepheline-feldspar products. The main products are the low-iron products Matrix 350, Spectrum and Minex, and Matrix 364 which may have a higher iron content $(0.5 \%)$ and a higher amount of trace minerals. Typical ranges for the mineral content of the low-iron products are 33-37\% nepheline, $45-51 \%$ K-feldspar, $12-14 \%$ plagioclase and 2-4\% pyroxene, while a typical composition for M364 is $27 \%$ nepheline, $45 \% \mathrm{~K}$-feldspar, $16 \%$ plagioclase and trace amounts of calcite, pyroxene, amphibole, titanite, biotite and zeolite.

The magnetic separation is done in several steps, first by low-intensity magnetic separation removing ferromagnetic minerals, and then by high-intensity magnetic separation to remove the remainder, less 
Table 1. Mineralogical variation of tailings. Abbreviations: LIMT - low-intensity magnetic tailings, HIMT - high-intensity magnetic tailings, n.d. - not detected

\begin{tabular}{lcccc}
\hline Mineral & LIMT & Dust tailings & HIMT-1 & HIMT-2 \\
\hline Mica & $1-2$ & $2-16$ & $6-14$ & $1-2$ \\
Nepheline & $17-19$ & $26-39$ & $16-18$ & $25-29$ \\
Feldspar & $24-33$ & $27-62$ & $26-30$ & $39-58$ \\
Calcite & $0-2$ & $3-7$ & $1-2$ & $5-9$ \\
Amphibole/pyroxene & $6-10$ & $4-23$ & $37-46$ & $4-6$ \\
Magnetite & $33-44$ & $0-1$ & 0 & 0 \\
Titanite/ilmenite & $\mathbf{4 - 5}$ & $\mathbf{1 - 4}$ & $\mathbf{2 - 3}$ & $\mathbf{0 - 1}$ \\
Quartz & n.d. & n.d. & n.d. & n.d. \\
\hline
\end{tabular}

magnetic $\mathrm{Fe}-\mathrm{Mg}$-containing minerals. The tailings from the process are mainly from the high- and low-intensity magnetic separation, and some fines from the dedusting process. All tailings streams are collected into one stream before being mixed with water and transported to the discharge point. The mineralogical variation of the tailings is high, with typical values given in Table 1. The tailings primarily consist of amphibole, pyroxene and biotite plus feldspar and nepheline. A small quantity of fine-grained, light-coloured minerals is released during processing and transport. The grain size of the tailings varies due to changes in the feed, but in general $90 \%$ is below $0.425 \mathrm{~mm}$ and $60 \%$ is above $0.045 \mathrm{~mm}$, with c. $85 \%$ in the fine silt to medium sand fraction (unpublished data).

\section{Methods}

The seabed in Lillebukt and Stjernsundet was mapped in September 2016 during a cruise with NGU's research vessel FF Seisma using a Kongsberg EM 2040 Dual RX multibeam echosounder. The echosounder was set to transmit signals (FM pulse, $200 \mathrm{kHz}$ ) in a fan of 130 degrees, and bathymetry and backscatter were recorded $200 \mathrm{~m}$ to each side. Neighbouring lines were run with approximately $50 \mathrm{~m}$ overlap. The data density was sufficient for gridding at $1 \mathrm{~m}$ bin size, allowing detailed analysis of seabed features. Lillebukt, down to $c .100 \mathrm{~m}$ water depth, was remapped with $300 \mathrm{kHz}$ frequency and medium CW pulse to obtain as high as possible data resolution in the shallowest area. Positioning was performed by Kongsberg Seapath $300+$, sound velocity profiles were recorded using a Valeport 650 sound velocity profiler, tidal corrections were obtained from the Norwegian Mapping Authority (www.havnivå.no), while CARIS software was used for data processing and ArcGIS for map production. Processed bathymetry and backscatter data are shown in Figs. 3 \& 4 .

An EM100 multibeam bathymetry dataset collected by the Norwegian Defence Research Institute (FFI) in 1998 was made available for the project to study depth changes (disposal volumes) in Lillebukt and on the submarine fan over the period 1998-2016. A slide occurred in the tailings at the shoreline in Lillebukt on $9^{\text {th }}$ October 2017. Following this, it was decided to remap Lillebukt to study depth changes caused by the slide. New data were collected in April 2018 with NGUs research vessel FF Seisma using the Kongsberg EM 2040 Dual RX multibeam echosounder and with the same instrument settings as in 2016.

High-frequency shallow seismic data (51 km; Fig. 3) were acquired using a Kongsberg TOPAS PS 40 parametric subbottom profiler. TOPAS uses a parametric acoustic source that forms a 5 degrees wide beam. The profiler was operated in chirp mode with primary frequencies of $36-39$ and $41-44 \mathrm{kHz}$, and chirp length of 10 milliseconds (ms). The returning signal was sampled within the frequency range $2-8 \mathrm{kHz}$ with a median frequency of $5 \mathrm{kHz}$. Such sampling frequency provides a vertical resolution of c. $0.2 \mathrm{~ms}(15 \mathrm{~cm})$ (Lepland et al., 2009). The seismic data were processed using TOPAS software.

Thirteen grab samples (Fig. 3) were collected in 2016 for characterisation of the mine tailings and seabed sediments. During a follow-up cruise with FF Seisma in 2017, coring with a Niemistö-corer and multicorer was performed at 17 stations to map the distribution and thickness of the mine tailings (Table 2). Cores with lengths up to $44 \mathrm{~cm}$ were retrieved. These were logged at NGU using a multi-sensor core logger (MSCL) measuring fractional porosity, wet bulk density (WBD), and magnetic susceptibility (MS) (www.geotek.co.uk; Dearing, 1994). After splitting of the cores, they were described and scanned using a system for colour photography and XRF geochemistry measurement with the MSCL (see Knies et al., 2018 for descriptions of methods).

Grain-size analysis was performed at NGU on 2-3 samples per core using a Coulter LS 200. This method gives mud (clay $(<0.002 \mathrm{~mm})+$ silt $(0.002-0.063 \mathrm{~mm})$ ) contents like other common methods for grain-size analyses (e.g., pipette and Sedigraph). However, the clay 


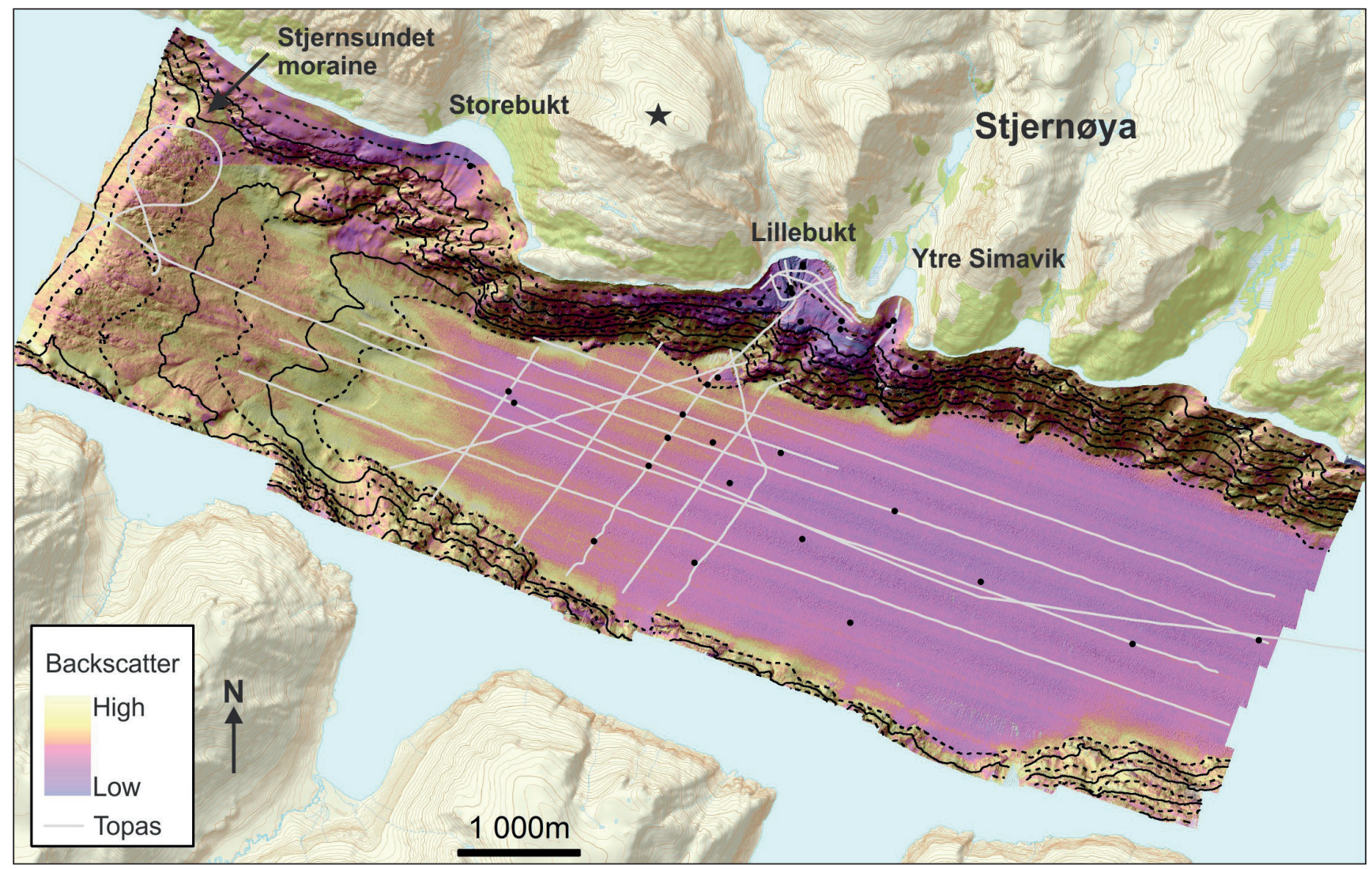

Figure 4. Multibeam backscatter intensity of the study area in Stjernsundet. White lines - TOPAS-profiles, black dots - grab and coring locations (numbered in Figs. 3, 5 \& 7), black asterix - location of present mine.

Table 2. Grab and core inventory.

\begin{tabular}{|c|c|c|c|c|c|c|c|}
\hline $\begin{array}{l}\text { Grab/core } \\
\text { number }\end{array}$ & Location & $\begin{array}{l}\text { Water depth } \\
\text { (m) }\end{array}$ & $\begin{array}{l}\text { North } X \\
\text { (UTM35) }\end{array}$ & $\begin{array}{c}\text { East } Y \\
(U T M 35)\end{array}$ & $\begin{array}{l}\text { Sampling } \\
\text { equipment }\end{array}$ & $\begin{array}{l}\text { Grab depth/ } \\
\text { core length } \\
\quad(\mathrm{cm})\end{array}$ & Descriptions/comments \\
\hline P1605001 & $\begin{array}{l}\text { Mid-distal } \\
\text { submarine fan } \\
\quad \text { (Unit A) }\end{array}$ & 450 & 334240 & 7800143 & Grab & 4 & $\begin{array}{l}\text { Black well sorted fine sand with } \\
\text { polychaetes }\end{array}$ \\
\hline P1605002 & $\begin{array}{c}\text { Margin of } \\
\text { submarine fan }\end{array}$ & 461 & 332597 & 7800249 & Grab & 10 & $\begin{array}{l}\text { Dark olive grey sandy mud, } 2 \\
\text { mm black fine sand on surface, } \\
\text { polychaetes and sea stars }\end{array}$ \\
\hline P1605003 & $\begin{array}{l}\text { Mid-distal } \\
\text { submarine fan } \\
\quad(\text { Unit A) }\end{array}$ & 460 & 333869 & 7799739 & Grab & 6 & $\begin{array}{l}\text { Black well sorted fine sand with shells } \\
<5 \mathrm{~mm}\end{array}$ \\
\hline P1605004 & $\begin{array}{c}\text { Outside } \\
\text { submarine fan }\end{array}$ & 466 & 333177 & 7798948 & Grab & 8 & $\begin{array}{l}\text { Dark olive grey sandy mud, } 2 \mathrm{~mm} \\
\text { black fine sand on surface, poly- } \\
\text { chaetes, shells and shell fragments }\end{array}$ \\
\hline P1605005 & $\begin{array}{c}\text { Outside } \\
\text { submarine fan }\end{array}$ & 461 & 335678 & 7798951 & Grab & 15 & $\begin{array}{l}\text { Olive grey mud, traces }(<1 \mathrm{~mm}) \\
\text { of dark fine sand on surface, many } \\
\text { polychaetes }\end{array}$ \\
\hline P1605006 & $\begin{array}{c}\text { Outside } \\
\text { submarine fan }\end{array}$ & 466 & 337525 & 7797667 & Grab & 17 & $\begin{array}{l}\text { Olive grey sandy mud, traces }(<1 \mathrm{~mm}) \\
\text { of black fine sand on surface, many } \\
\text { polychaetes }\end{array}$ \\
\hline P1605007 & Ytre Simavik & 62 & 33596 & 7800117 & Grab & 8 & $\begin{array}{l}\text { Grey gravelly sandy mud with pebbles } \\
<6 \mathrm{~cm},<3 \mathrm{~mm} \text { light grey mud on } \\
\text { surface, many small green sea urchins } \\
\text { and some shells }\end{array}$ \\
\hline P1605008 & Ytre Simavik & 43 & 335822 & 7800518 & Grab & 10 & $\begin{array}{l}\text { Greyish brown mud }(3 \mathrm{~cm}) \text { above } \\
\text { firm greyish black mud }(7 \mathrm{~cm}), \\
<5 \text { mm light grey mud on surface, } \\
\text { many small green sea urchins and } \\
\text { some shells }\end{array}$ \\
\hline
\end{tabular}


Table 2. (Continued)

\begin{tabular}{|c|c|c|c|c|c|c|c|}
\hline $\begin{array}{l}\text { Grab/core } \\
\text { number }\end{array}$ & Location & $\begin{array}{l}\text { Water depth } \\
(m)\end{array}$ & $\begin{array}{l}\text { North X } \\
\text { (UTM35) }\end{array}$ & $\begin{array}{l}\text { East } Y \\
(U T M 35)\end{array}$ & $\begin{array}{l}\text { Sampling } \\
\text { equipment }\end{array}$ & $\begin{array}{l}\text { Grab depth/ } \\
\text { core length } \\
\quad(\mathrm{cm})\end{array}$ & Descriptions/comments \\
\hline P1605009 & Eastern Lillebukt & 47 & 335395 & 7800558 & Grab & 10 & $\begin{array}{l}\text { Greyish brown mud }(3 \mathrm{~cm}) \text { above } \\
\text { firm greyish black mud }(7 \mathrm{~cm}) \text {, } \\
<5 \text { mm light grey mud on surface, } \\
\text { many small green sea urchins and } \\
\text { some shells }\end{array}$ \\
\hline P1605010 & $\begin{array}{l}\text { Channel levee, } \\
\text { Lillebukt }\end{array}$ & 71 & 335058 & 7800586 & Grab & 4 & Light grey mud \\
\hline P1605011 & Western Lillebukt & 63 & 334565 & 7800784 & Grab & 7 & $\begin{array}{l}\text { Greyish brown mud }(3 \mathrm{~cm}) \text { above } \\
\text { firm greyish black mud }(5 \mathrm{~cm}) \text {, } \\
<5 \text { mm light grey mud on surface, } \\
\text { many small green sea urchins and } \\
\text { polychaetes and some shells }\end{array}$ \\
\hline P1605012 & $\begin{array}{l}\text { Channel, axis, } \\
\text { Lillebukt }\end{array}$ & 56 & 335000 & 7800870 & Grab & 16 & $\begin{array}{l}0-5 \mathrm{~cm} \text { : fine- to medium-grained } \\
\text { cross laminated layers of black sand } \\
\text { alternating with thin mud laminae. } \\
5-13 \mathrm{~cm} \text { : grey mud }\end{array}$ \\
\hline $\mathrm{P} 1605013$ & $\begin{array}{l}\text { Channel levee, } \\
\text { Lillebukt }\end{array}$ & 18 & 335122 & 7801052 & Grab & 3 & Light grey mud \\
\hline P1707001 & $\begin{array}{c}\text { West of } \\
\text { submarine fan }\end{array}$ & 461 & 332645 & 7800150 & Multicorer & 17 & $\begin{array}{l}\text { Massive, olive grey sandy mud with a } \\
\text { transition to olive grey muddy sand } \\
\text { at its base }\end{array}$ \\
\hline P1707002 & $\begin{array}{l}\text { Margin of } \\
\text { submarine fan }\end{array}$ & 463 & 333689 & 7799524 & Multicorer & 9 & Massive, olive grey muddy sand \\
\hline P1707003 & $\begin{array}{l}\text { Southern margin of } \\
\text { Stjernsundet }\end{array}$ & 465 & 333994 & 7798700 & Multicorer & 13 & $\begin{array}{l}\text { Olive grey sandy mud in their upper } \\
\text { parts and muddy sand in their lower } \\
\text { parts }\end{array}$ \\
\hline P1707004 & $\begin{array}{c}\text { East of } \\
\text { submarine fan }\end{array}$ & 462 & 336327 & 7798299 & Niemistöcorer & 37 & Sandy mud \\
\hline P1707005 & $\begin{array}{c}\text { Far east of } \\
\text { submarine fan }\end{array}$ & 475 & 338580 & 7797590 & Niemistöcorer & 30 & Sandy mud \\
\hline P1707006 & Western Lillebukt & 59 & 334751 & 7800767 & Multicorer & 0 & 2 attempts with Niemistöcorer failed \\
\hline P1707007 & & 14 & 335387 & 7800483 & Multicorer & 14 & \\
\hline P1707008 & Ytre Simavik & 53 & 335783 & 7800479 & Multicorer & 13 & $\begin{array}{l}\text { Massive, light greyish sandy mud } \\
\text { with shells and shell fragments and an } \\
\text { upward increase in mud content and } \\
\text { lighter colour near the top }\end{array}$ \\
\hline P1707009 & & 54 & 332467 & 7802123 & Multicorer & 4 & \\
\hline P1707010 & $\begin{array}{l}\text { Channel axis, } \\
\text { Lillebukt }\end{array}$ & 64 & 334998 & 7800820 & Multicorer & 22 & $\begin{array}{l}\text { Massive, light grey mud with } 3 \mathrm{~cm} \\
\text { of black, fine- to medium-grained } \\
\text { laminated sand at the top and some } \\
\text { spots of dark sand in the mud }\end{array}$ \\
\hline P1707011 & $\begin{array}{l}\text { Channel levee, } \\
\text { Lillebukt }\end{array}$ & 23 & 335110 & 7801035 & Multicorer & 0 & \\
\hline P1707013 & $\begin{array}{c}\text { Distal } \\
\text { submarine fan }\end{array}$ & 459 & 334797 & 7799516 & Multicorer & 19 & $\begin{array}{l}\text { Olive grey, gravelly muddy sand } \\
\text { with some layering and small shell } \\
\text { fragments }\end{array}$ \\
\hline P1707014 & $\begin{array}{c}\text { Middle } \\
\text { submarine fan }\end{array}$ & 457 & 334019 & 7799909 & Grab & 0 & \\
\hline P1707015 & $\begin{array}{c}\text { Proximal } \\
\text { submarine fan }\end{array}$ & 445 & 334338 & 7800183 & Grab & 0 & \\
\hline P1707016 & $\begin{array}{l}\text { Southern margin of } \\
\text { Stjernsundet }\end{array}$ & 463 & 335230 & 7798062 & Niemistöcorer & 30 & $\begin{array}{l}\text { Olive grey sandy mud in their upper } \\
\text { parts and muddy sand in their lower } \\
\text { parts }\end{array}$ \\
\hline P1707017 & $\begin{array}{l}\text { Southeast of } \\
\text { submarine fan }\end{array}$ & 463 & 334903 & 7798791 & Niemistöcorer & 33 & Sandy mud \\
\hline P1707018 & $\begin{array}{l}\text { Margin of } \\
\text { submarine fan }\end{array}$ & 462 & 334355 & 7799312 & Niemistöcorer & 32 & $\begin{array}{l}\text { Olive grey sandy mud with an erosive, } \\
\text { black sand layer at } 13-14 \mathrm{~cm}\end{array}$ \\
\hline P1707019 & $\begin{array}{l}\text { Mid-distal } \\
\text { submarine fan }\end{array}$ & 459 & 334247 & 7799658 & Niemistöcorer & 0 & \\
\hline P1707020 & $\begin{array}{c}\text { Far east of } \\
\text { submarine fan }\end{array}$ & 480 & 343315 & 7796312 & Niemistöcorer & 44 & Sandy mud \\
\hline
\end{tabular}


content is much lower and the silt content much higher than for the other methods. To compensate for this, we have used the formula ( $4 \mathrm{x}$ percentage clay $<2 \mu \mathrm{m}$ from Coulter + percentage clay $<7.4 \mu \mathrm{m}$ from Coulter) / 2 (Rise, 2013) to calculate the equivalent clay content in the samples. Silt constitutes the remaining part of the mud fraction. Mineralogical analyses were carried out by XRD on unoriented preparations scanned by a Bruker D8 Advance diffractometer $\left(\mathrm{Cu} K_{\mathrm{a}}\right.$ radiation in $3-75^{\circ} 2$ range). Mineral identification was carried out with an automatic and/or manual peak search and match function in Bruker's Diffraction EVA V3.1 software. Mineral quantification was performed using Rietveld modelling with software TOPAS 5.

\section{Results}

\section{Seabed morphology and time lapse bathymetry}

Several channels occur at the seabed in the inner part of Lillebukt (Fig. 5). The starting point of the deepest channel is at the outlet of the river from lake Lillebuktvannet (the local name is Vanskeligvann; Fig. 2). It reaches a maximum width of almost $180 \mathrm{~m}$ at $10-20 \mathrm{~m}$ water depth, and locally more than $12 \mathrm{~m}$ depth. Another channel has its starting point at the tailings outlet, $c .100$ $\mathrm{m}$ west of the river outlet. An up to $14 \mathrm{~m}$-high levee is developed along the western margin of this channel. At 10-35 $\mathrm{m}$ water depth, the two channels are separated by a N-S-trending sediment ridge/levee. A smaller channel has its starting point in shallow water between the river mouth and the passenger quay to the east (Fig. 5). This channel has a width of 20-30 m and a depth of up to $7 \mathrm{~m}$. The channel margins slope at up to $35^{\circ}$.

The three channels meet c. $400 \mathrm{~m}$ from the shore in around $60 \mathrm{~m}$ water depth, where a single channel with an up to $10 \mathrm{~m}$-high southeastern levee continues for another $300 \mathrm{~m}$ to almost $100 \mathrm{~m}$ depth (Fig. 5). From the base of the channel to the top of the levee, the elevation difference is almost $30 \mathrm{~m}$. Small slide scars, typically $10-20 \mathrm{~m}$ across and $20-30 \mathrm{~m}$ long, occur in the levee. The channel ends at the edge towards the steep, bedrock fjord slope. Ten to fifteen smaller channels can be traced from the shore in the eastern part of Lillebukt towards deeper areas (Fig. 5). These are up to $300 \mathrm{~m}$ long, 1-2 m deep and 10-30 $\mathrm{m}$ wide.

Sediment waves and current ripples are common in the channels. At depths shallower than $60 \mathrm{~m}$, sediment waves are typically up to c. $1 \mathrm{~m}$ high with wavelengths of $10-15 \mathrm{~m}$. Deeper than $60 \mathrm{~m}$, they are up to $3 \mathrm{~m}$ high with wavelengths of 15-20 m. Away from the channels, the seabed is relatively even, sloping 10-15 degrees from the shore. The slope along the main channel system, from the shore to $100 \mathrm{~m}$ water depth, is $\mathrm{c} .10^{\circ}$. A bedrock gully, sloping at $45-50^{\circ}$, continues from the termination of the main channel down to c. $400 \mathrm{~m}$ depth (Fig. 5).

A generally smooth seafloor in Lillebukt indicates that all channels are developed in sediments/tailings with one possible exception; an irregular channel directed towards the shore $50 \mathrm{~m}$ east of the passenger quay (Fig. 5). The seabed along this channel is irregular and rugged, indicating underlying slide material and/or bedrock. A slide fan occurs on the seabed in 40-60 $\mathrm{m}$ water depth, at the mouth of the channel (Fig. 5). The source area for the slide is apparently at the beach or road south or east of the passenger quay.

A slide scar with a 300 m-long, NNE-SSW-trending, diffuse head escarpment occurs in the western part of Lillebukt only a few metres from the main quay (Fig. 5). The slide scar and the escarpment, which is $3-5 \mathrm{~m}$ high (highest in the south), are buried by tailings. Small channels within the slide scar trend south-southeast.

A new EM2040 multibeam dataset was collected in Lillebukt in 2018. The main objective was to assess depth changes related to the shoreline slide at the tailings outlet on $9^{\text {th }}$ October 2017. Depth differences between the bathymetry datasets collected in 2016 and 2018 are compared in Fig. 6 and draped on the 2016 shaded relief bathymetry. It is evident that changes are up to $\pm 3 \mathrm{~m}$, with erosion mainly in the channel south of the river outlet (Figs. 5 \& 6) and on the sides of the levees, while there has been sediment accumulation in the channel south of the tailings outlet. It appears that the crests of some sandwaves have migrated up to $c .20 \mathrm{~m}$, while other sandwaves have either disappeared or been created. Slide scars or sediment blocks related to sliding are not observed.

A convex submarine fan has accumulated at the foot of the fjord slope, extending to c. $463 \mathrm{~m}$ water depth (Fig. 7). The slope of the fan surface changes from $c .15^{\circ}$ in its proximal part to around $10^{\circ}$ in the mid-fan area to less than $4^{\circ}$ in distal parts. The fan has a radius of up to 1500 $\mathrm{m}$ and covers an area of c. $1.5 \mathrm{~km}^{2}$.

Bathymetry data collected by the Norwegian Defence Research Institute (FFI) in 1998 were compared with the new bathymetry data collected in 2016. The data collected in 1998 were gridded at $5 \mathrm{~m}$ due to lower quality. However, the depth contours along the southern part of Stjernsundet are almost identical while depths have decreased over the submarine fan. The time lapse data show that the submarine fan has expanded both laterally and vertically, and that there has been a thickness increase of the most proximal part of the fan of more than $7 \mathrm{~m}$ (Fig. 8). We interpret this to be related to tailings disposal with only a minor component of natural deposition. The comparison shows a volume increase in the submarine fan of 1.5-2.3 million $\mathrm{m}^{3}$ over the 18-year period. The higher number represents an assumed 0.5 
$m$ error margin in the thickness calculation due to the lower quality of the 1998 dataset. The 1998 bathymetry data do not cover the areas closest to the shore, but the data from Lillebukt indicate a generally positive accumulation down to $80 \mathrm{~m}$ water depth. The data show that the channels occur in stable positions; there has been neither lateral migration nor channel switching. Tailings accumulation along the shore is evident from observed shallowing along the quays and diffuse appearance/ burial of the slide scar in the western part of the bay.
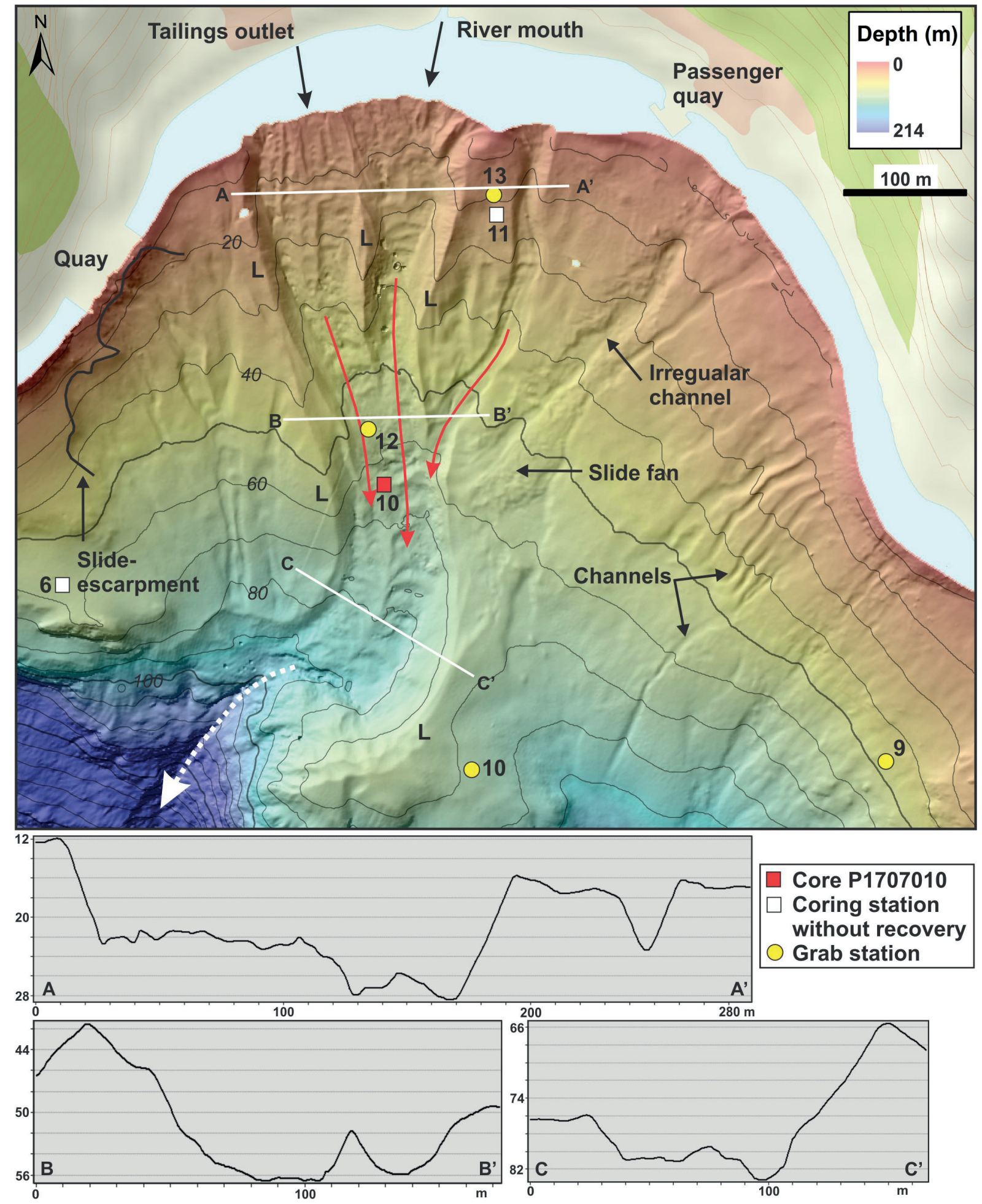

Figure 5. Shaded relief multibeam bathymetry (10 m contours) of the study area in Lillebukt and bathymetric profiles A-C. The topography is illuminated from the northwest. Red arrows - thalwegs of main channels, white dashed arrow - gully in bedrock fjord slope, $L-$ channel levee. Only the last figures in grab and core numbers are shown (see Table 2 for complete numbers). 

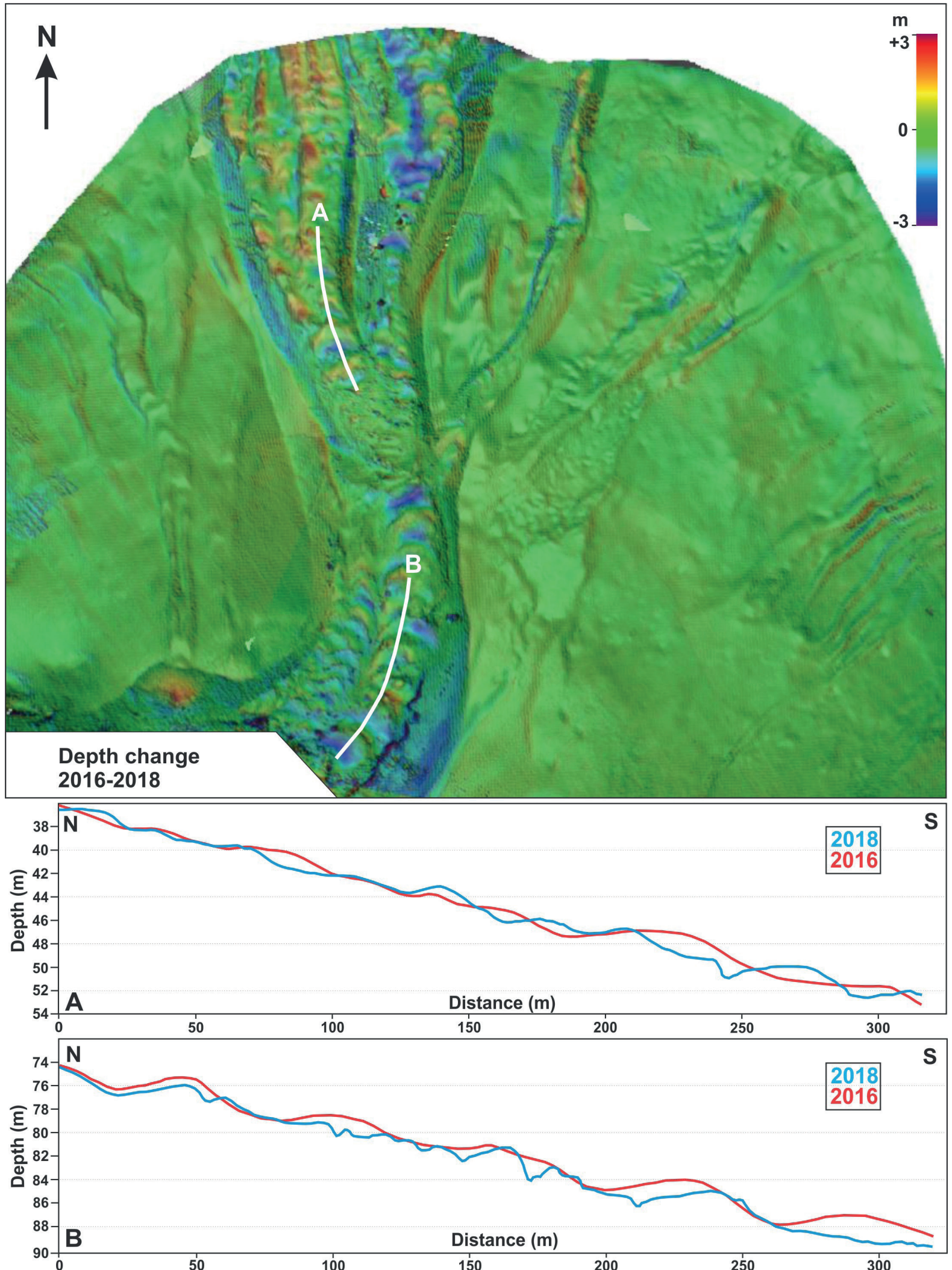

Figure 6. Depth change in Lillebukt between September 2016 and April 2018. The difference map is based on EM2040 multibeam bathymetry collected by NGU. Depth changes are up to $\pm 3 \mathrm{~m}$, with erosion mainly in the channel south of the river outlet (Fig. 5) and on the sides of the levees, while there has been sediment accumulation in the channel south of the tailings outlet. Some sandwaves have migrated 20-30 m, while other sandwaves have either disappeared or been created. 


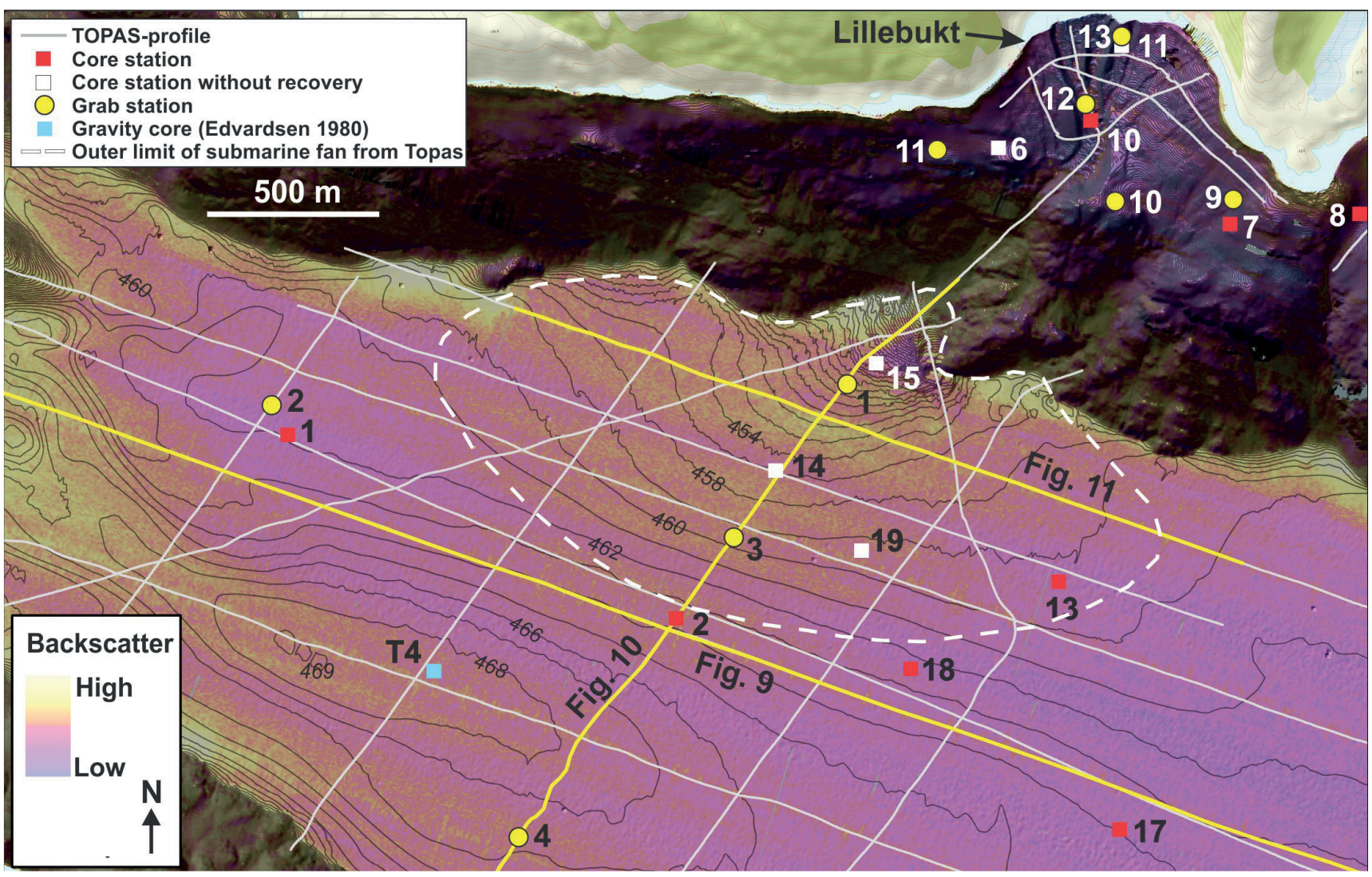

Figure 7. Multibeam backscatter intensity map with superimposed $1 \mathrm{~m}$ depth contours of the submarine fan southwest of Lillebukt in Stjernsundet. TOPAS profiles shown in Figs. 9-11 are shown in yellow. Only the last figures of grab and core numbers are shown (see Table 2 for complete numbers). Outer limit of submarine fan is based on the TOPAS data.

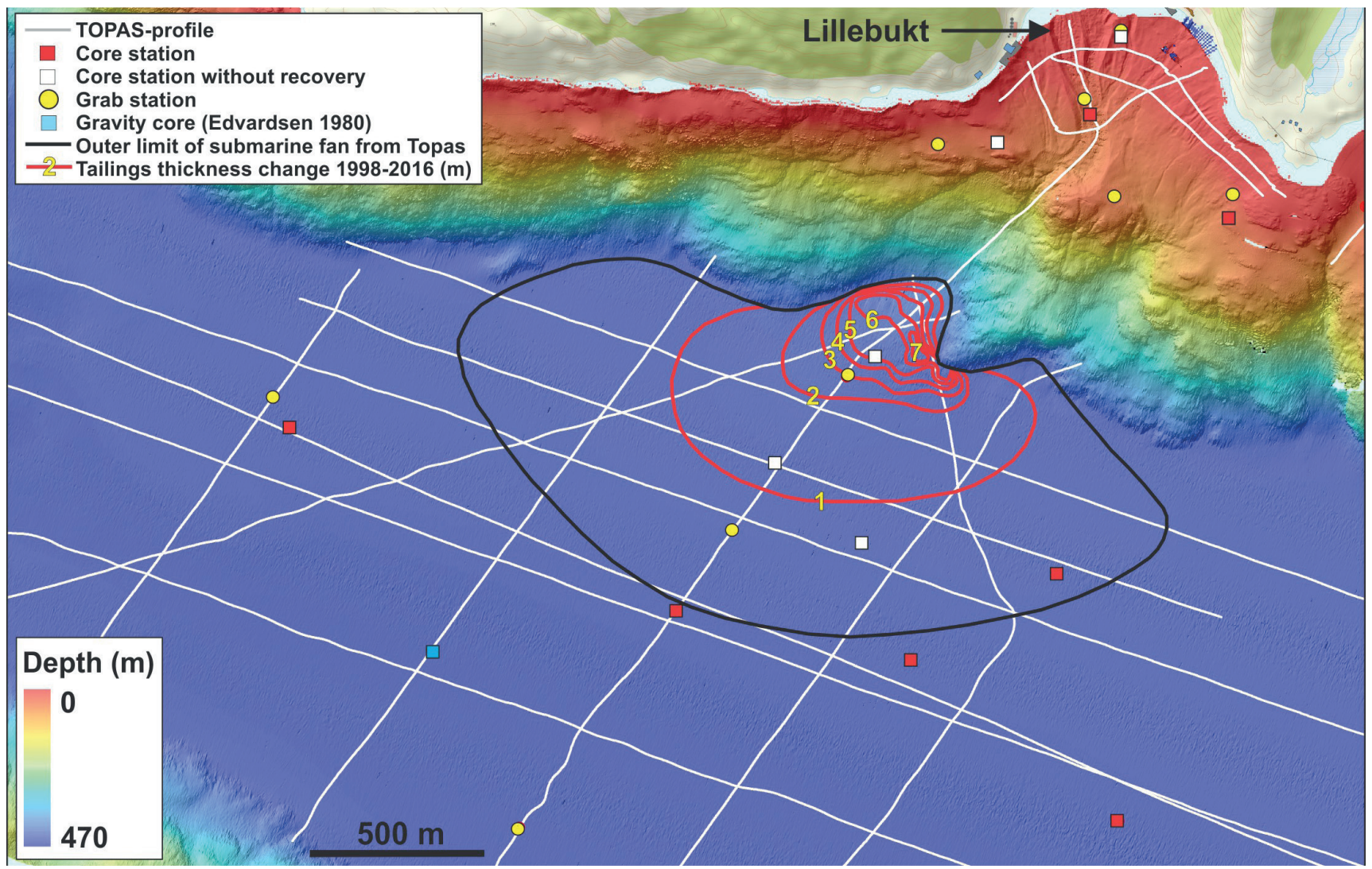

Figure 8. Thickness of tailings deposited on the submarine fan between 1998 and 2016 based on time lapse multibeam bathymetry. 


\section{Seismic stratigraphy}

TOPAS data from Lillebukt show a relatively poorly defined upper unit that is $1-2 \mathrm{~m}$ thick but locally, in channel levees, up to $5 \mathrm{~m}$. The upper unit is massive to stratified, overlying an acoustically transparent and structureless unit of unknown thickness. Unpublished boomer data indicate that the Quaternary succession in Stjernsundet is several hundred metres thick. Lodgement till probably occurs at the base. This is overlain by the Stjernsundet Moraine, while glaciomarine sediments occur in the fjord basins east and west of the moraine. The uppermost part of the sediment succession can be studied in the new TOPAS data and is divided into several seismic units (Figs. 9-11). Unit A occurs at the seabed southwest of Lillebukt, where it forms a submarine fan with convex topography draped against the rocky fjord slope (Fig. 10). The unit is acoustically transparent with a massive and structureless seismic signature (Fig. 11). Its thickness changes from a maximum of $12-14 \mathrm{~m}$ at the fan apex near the gully in the steep, rocky fjord slope, to almost zero $c .1 .5 \mathrm{~km}$ out from the apex. Unit A downlaps onto the underlying unit.

A weak reflector marks the boundary between Units A and B (Figs. 10 \& 11). South of Lillebukt, Unit B is 8-9 $m$ thick and acoustically transparent with only a few, very weak reflectors in its upper part (the strongest is shown by a dashed line in Figs. 10 \& 11). It thins towards the west and is absent due to erosion in a c. 10

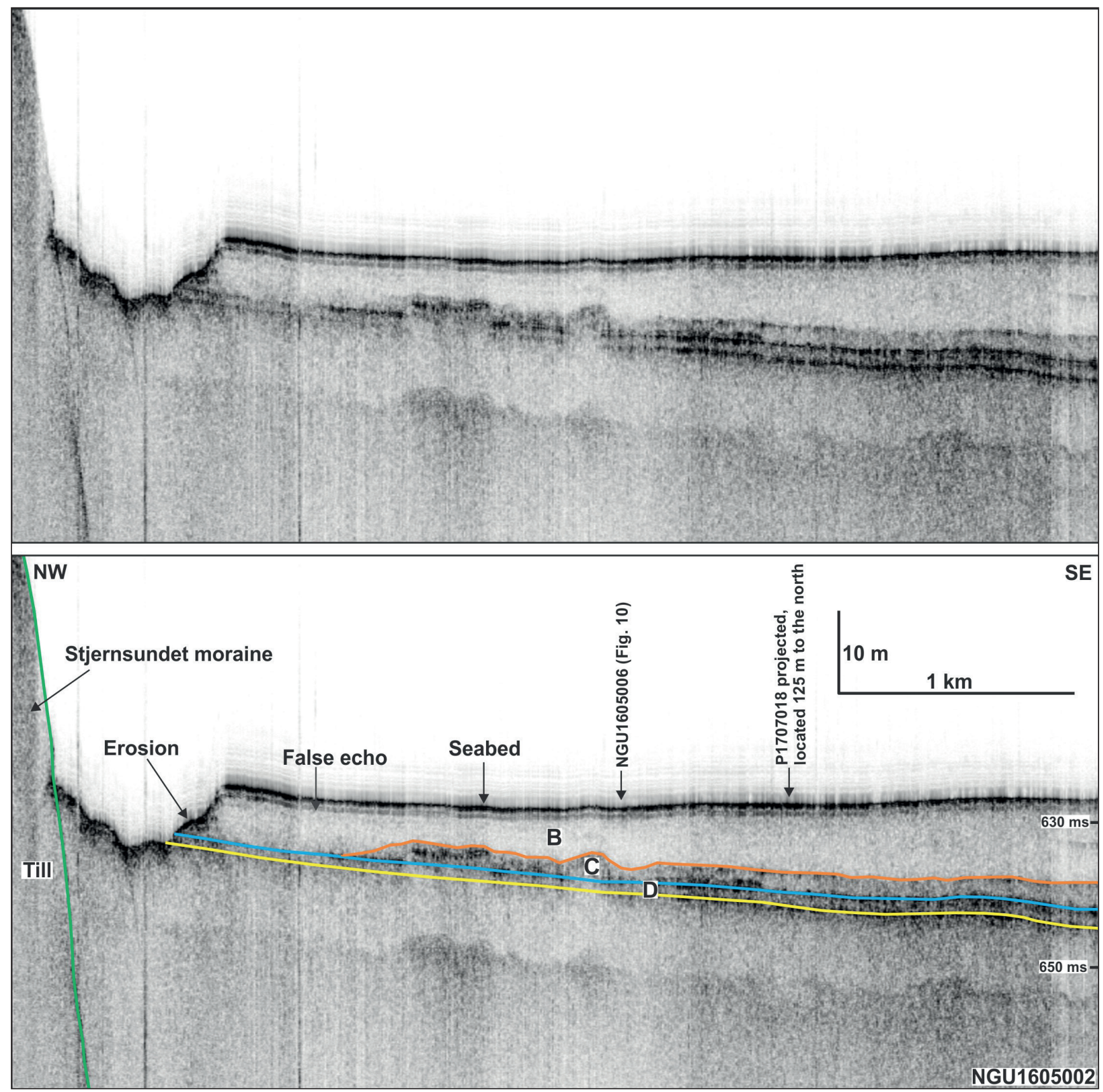

Figure 9. TOPAS profile along Stjernsundet with interpreted seismic units (see main text for interpretation). See Figs. 3 \& 7 for location of the line. 


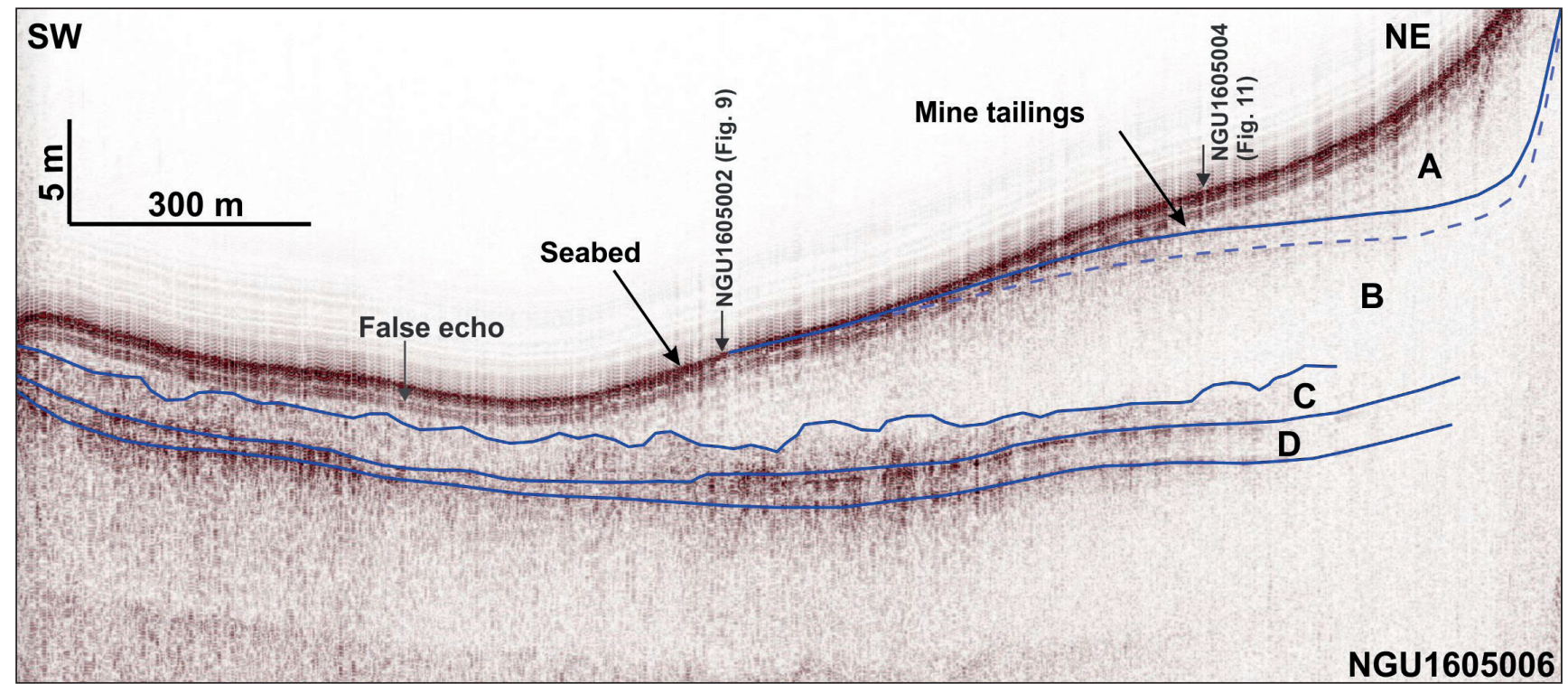

Figure 10. TOPAS profile from the apex (proximal NE part) of the submarine fan towards its distal part. See main text for interpretation of the units and Figs. 3 \& 7 for location of the line.

$\mathrm{m}$-deep and 600-700 m-wide trench along the foot of the Stjernsundet Moraine (Fig. 9). Eastwards, it reaches 11-12 m thickness and locally exhibits a few slightly more distinct reflectors. Its thickness is gradually reduced to 3-4 $\mathrm{m}$ in a southwesterly direction towards the deepest part of the fjord south of Lillebukt (Fig. 10), while along the steep southern fjord slope it has been removed by erosion.

Unit C is c. $2 \mathrm{~m}$ thick and acoustically massive to transparent (Figs. 9-11). Towards the east, its thickness increases to c. $3 \mathrm{~m}$, while towards the west it thins to zero.
Its upper boundary towards Unit B is locally indistinct and hummocky, especially in the central part of the fjord southwest of Lillebukt, where the relief reaches 1-2 m (Figs. 9 \& 10). Its lower boundary is characterised by a strong and continuous reflector. Unit D is stratified with an even thickness of almost $2 \mathrm{~m}$. Erosion has penetrated through it and into underlying strata along the foot of the Stjernsundet moraine (Fig. 9). A strong and continuous reflector occurs along the base of Unit D. A strong reflector also occurs in its uppermost part (Fig. 11).

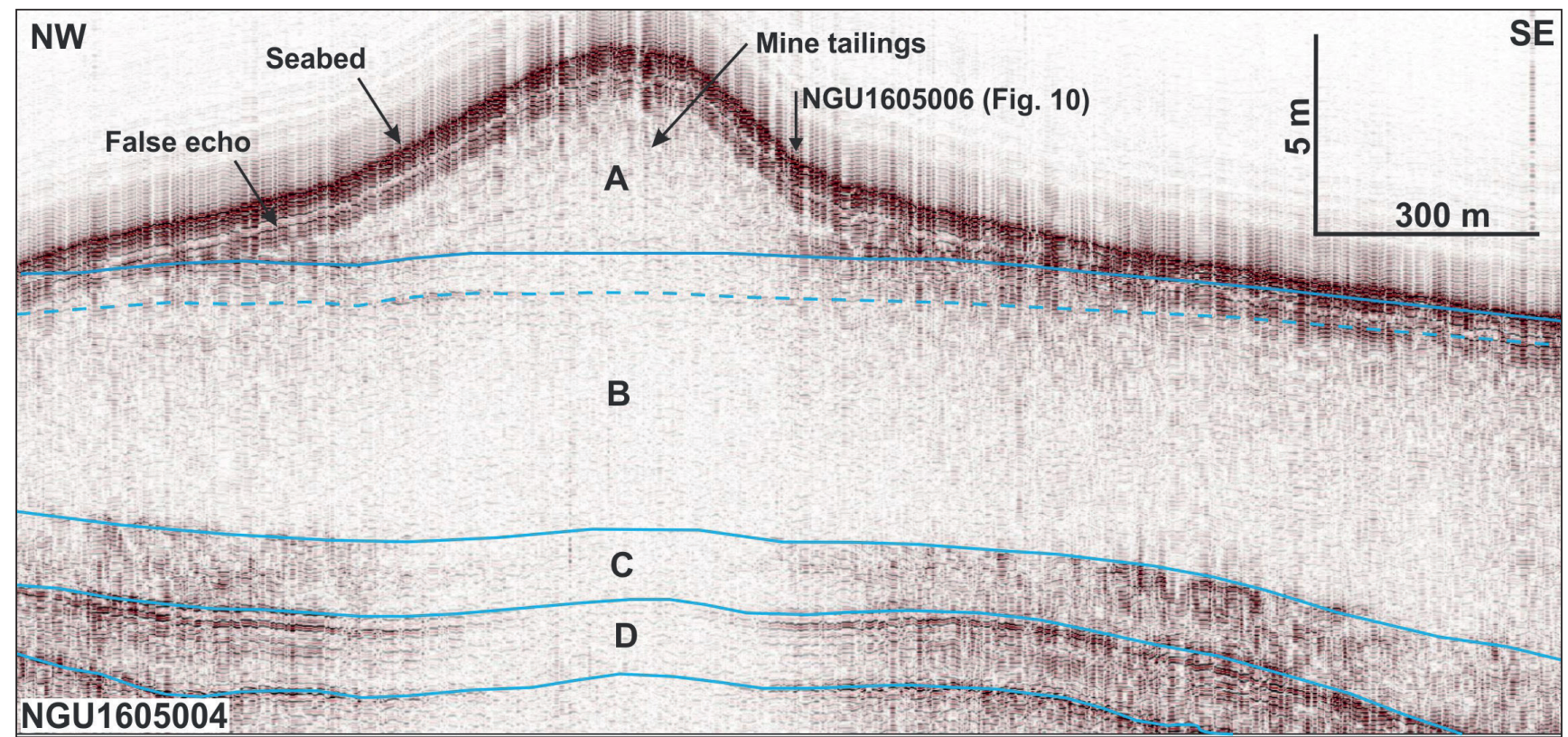

Figure 11. TOPAS profile across the submarine fan, along Stjernsundet. See main text for interpretation of the units and Figs. 3 \& 7 for location of the line. 


\section{Seabed sediment descriptions}

Multibeam data from Lillebukt and the deep Stjernsundet fjord basin show low backscatter intensities, indicating relatively fine-grained sediments (Fig. 4). Channels in Lillebukt and the surface of the submarine fan are characterised by medium backscatter intensities, while the steep fjord slopes exhibit intensities varying from high to low. The moraine in the west is characterised by medium to high backscatter intensities, indicating coarse-grained sediments and/or a firm seabed. Grab samples and cores were taken from various settings (Figs. 3-5 \& 7-8) to characterise the seabed sediments and the mine tailings. Table 2 summarises the details of the grabs and cores, while the cores are further described below.

Seven grab samples and three sediment cores were taken in the shallow areas along the coast. All samples and cores from Lillebukt are from the upper unit. Core P1707007 from the eastern part of Lillebukt (Fig. 7) comprises a light greyish sandy mud with an upward increase in mud content and lighter colour near the top (Fig. 2C). WBD varies from 1.8 to $1.9 \mathrm{~g} / \mathrm{cm}^{2}$, while the MS increases downwards from 600 to $900 \times 10^{-5} \mathrm{SI}$.

Core P1707010 from the main channel in Lillebukt (Fig. 7) exhibits massive, light grey mud with $3 \mathrm{~cm}$ of black, fine- to medium-grained, laminated sand at the top and some spots of dark sand in the mud (Figs. 12C \& 13). The contact between the mud and the sand is sharp/erosive. BWD increases from $1.6-1.8 \mathrm{~g} / \mathrm{cm}^{2}$ in the lower part to more than $2.2 \mathrm{~g} / \mathrm{cm}^{2}$ in the sand layer at the top. MS decreases downwards from 6500 in the sand layer at the top to $150 \times 10^{-5} \mathrm{SI}$ at the base.

Core P1707008 from Ytre Simavik (Fig. 7) comprises massive, light greyish sandy mud with shells and shell fragments and an upward increase in mud content and lighter colour near the top (Fig. 12C). WBD is $1.8-1.9 \mathrm{~g} /$ $\mathrm{cm}^{3}$, while MS increases downwards from 550 to $700 \times 10^{-5}$ SI.

Core P1707001 from the area west of the submarine fan (Fig. 7) comprises massive, olive grey sandy mud with a transition to olive-grey muddy sand at its base (Fig. 12A). WBD is $1.8-2.0 \mathrm{~g} / \mathrm{cm}^{2}$, while MS varies between 900 and $1300 \times 10^{-5}$ SI. Core P1707002 from the southwestern margin of the submarine fan (Fig. 7) comprises massive, olive-grey muddy sand (Fig. 12A). WBD varies from 1.9 to $2.1 \mathrm{~g} / \mathrm{cm}^{2}$, while MS increases downwards from 2300 to $2700 \times 10^{-5}$ SI. Core P1707013 from the distal, southeastern part of the submarine fan (Fig. 7) comprises olive-grey, gravelly, muddy sand with some layering and small shells (Fig. 12A). WBD varies from 1.7 to $1.9 \mathrm{~g} / \mathrm{cm}^{2}$, while MS increases downwards from 900 to $1300 \times 10^{-5} \mathrm{SI}$.

Core P1707018 taken just southeast of the submarine fan (Fig. 7) comprises olive-grey sandy mud with an erosive, black sand layer at 13-14 cm (Figs. 12A \& 14). The sand layer and the 3-4-cm interval underneath contains many small white shells. The lower part of the core contains less sand and is lighter coloured than the upper part. WBD increases upwards from $1.5 \mathrm{~g} / \mathrm{cm}^{2}$ to a maximum of $2.1 \mathrm{~g} / \mathrm{cm}^{2}$ in the sand layer, while in the upper part of the core WBD is around $1.9 \mathrm{~g} / \mathrm{cm}^{2}$ (Fig. 14). MS increases downwards from 1100 to $1300 \times 10^{-5} \mathrm{SI}$ in the sand layer then decreases to 200 in the lower part of the core.

Cores P1707003 and P170716 from the southern margin of Stjernsundet (Fig. 3) comprise olive-grey sandy mud in their upper parts and muddy sand in their lower parts (Fig. 12B). Small shells occur through the cores. Several darker coloured, more sandy layers occur in the lower part of core P1607016. WBD varies from 1.8 to $2.0 \mathrm{~g} / \mathrm{cm}^{2}$ in both cores while MS is $700-1000 \times 10^{-5} \mathrm{SI}$.

Cores P1707017, P1707004, P1707005 and P170720 make up a transect along central Stjernsundet from south of Lillebukt (southeast of the submarine fan) to the eastern part of Stjernsundet (Figs. $1 \& 3$ ). They comprise sandy mud throughout, with an increasing mud content towards the east (95\% in the easternmost core P1707020; Fig. 12B). The cores exhibit some diffuse layers, dark spots/bioturbation and small shells. BWD varies from 1.5 to $1.7 \mathrm{~g} / \mathrm{cm}^{2}\left(1.8 \mathrm{~g} / \mathrm{cm}^{2}\right.$ in the upper part of core $\mathrm{P} 1707017)$ while the MS is $100-300 \times 10^{-5} \mathrm{SI}$.

\section{XRF and XRD results}

Titanium-normalised, major element profiles exhibit lower values in the upper parts of the studied cores, where MS values have a clear increasing trend (Figs. 13 \& 14). The XRD quantifications show that the sediments in the lower part of the cores both in the channel in Lillebukt (core P1707010; Fig. 5) and at the edge of the tailings fan in Stjernsundet (core P1707018; Fig. 7) are dominated by quartz, plagioclase and mica with relatively high biogenic calcite debris at the bottom of the fjord (Table 3). The material in the upper part of the cores is considerably coarser in the channel (core P1707010, 95\% sand) compared with the fjord bottom (P1707018; 50\% sand), but despite this grain-size contrast the mineral composition is rather similar with high abundances of potassium feldspar, nepheline and plagioclase, albeit pyroxene and amphibole abundances are higher in the coarse tailings in the channel (Table 3). 


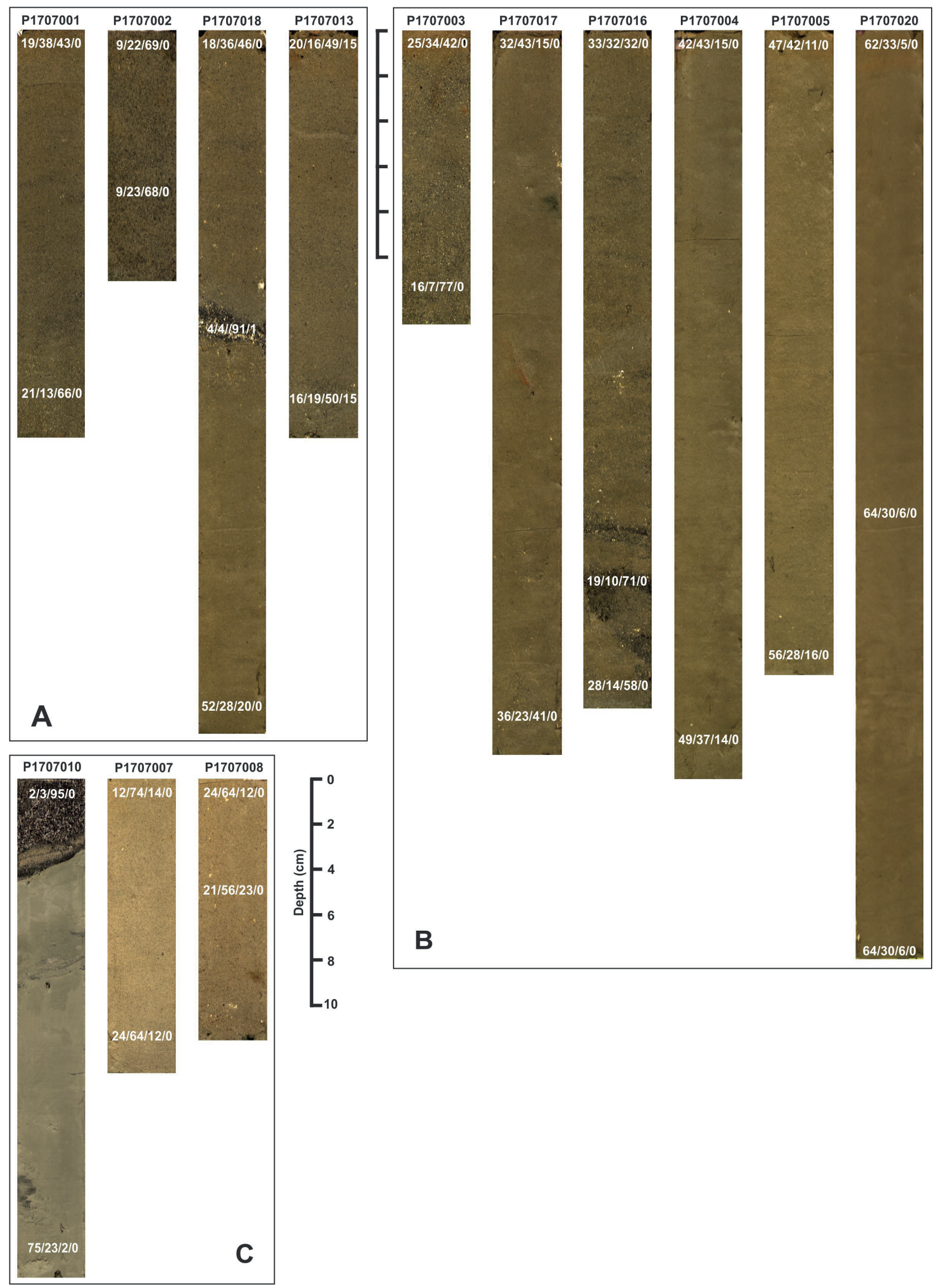

Figure 12. Multisensor core logger (MSCL) photographs of cores from Stjernsundet and Lillebukt. Results from the grain-size analyses are shown as percentage clay/silt/sand/gravel (white numbers). (A) Cores along and outside the margin of the submarine fan. (B) Cores in distal positions to the submarine fan. (C) Cores from Lillebukt and Ytre Simavik. See Figs. 1, 3, 5 \& 7 for location of the cores. 


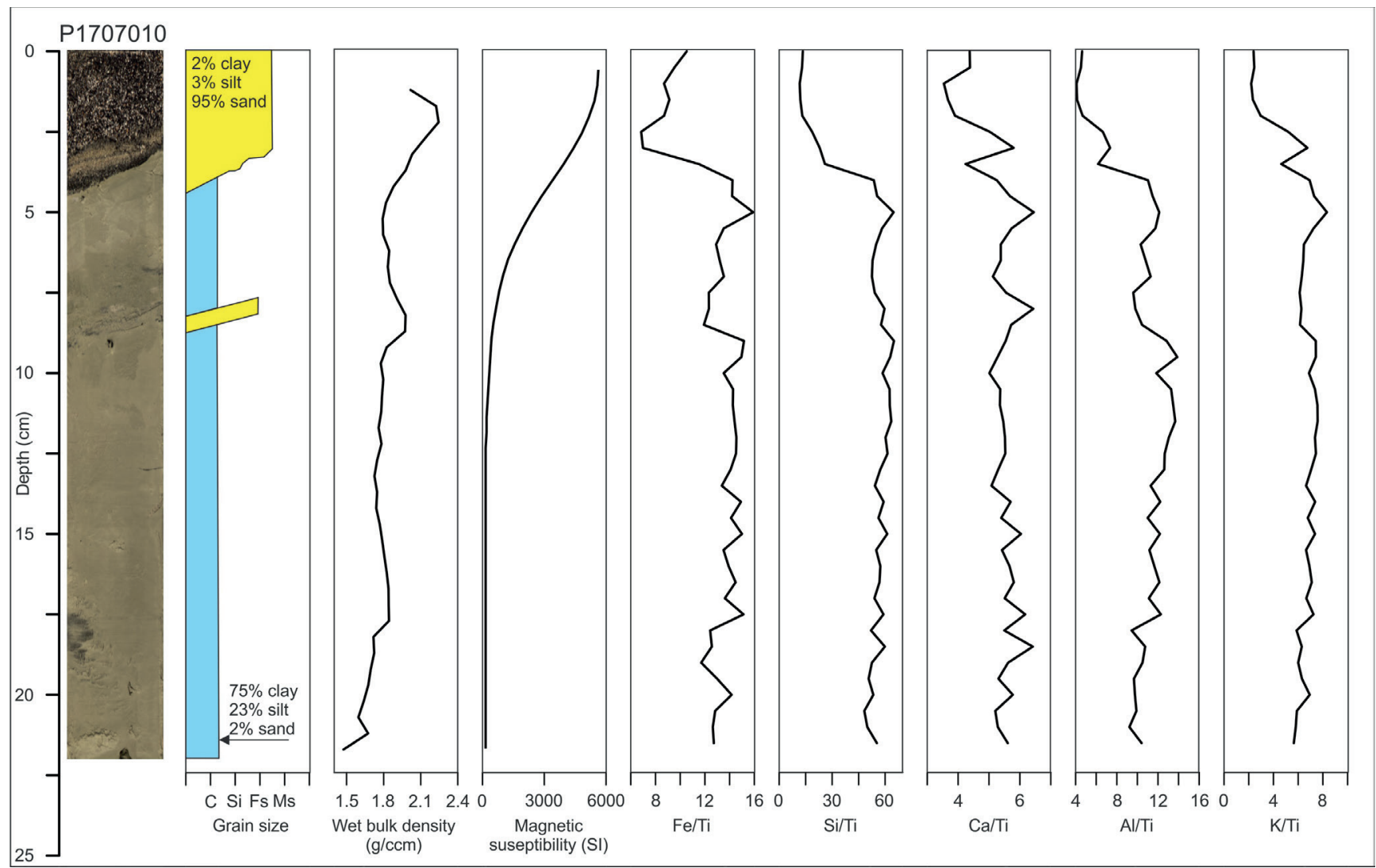

Figure 13. Multisensor core logger (MSCL), XRF and grain-size results for core P1707010.

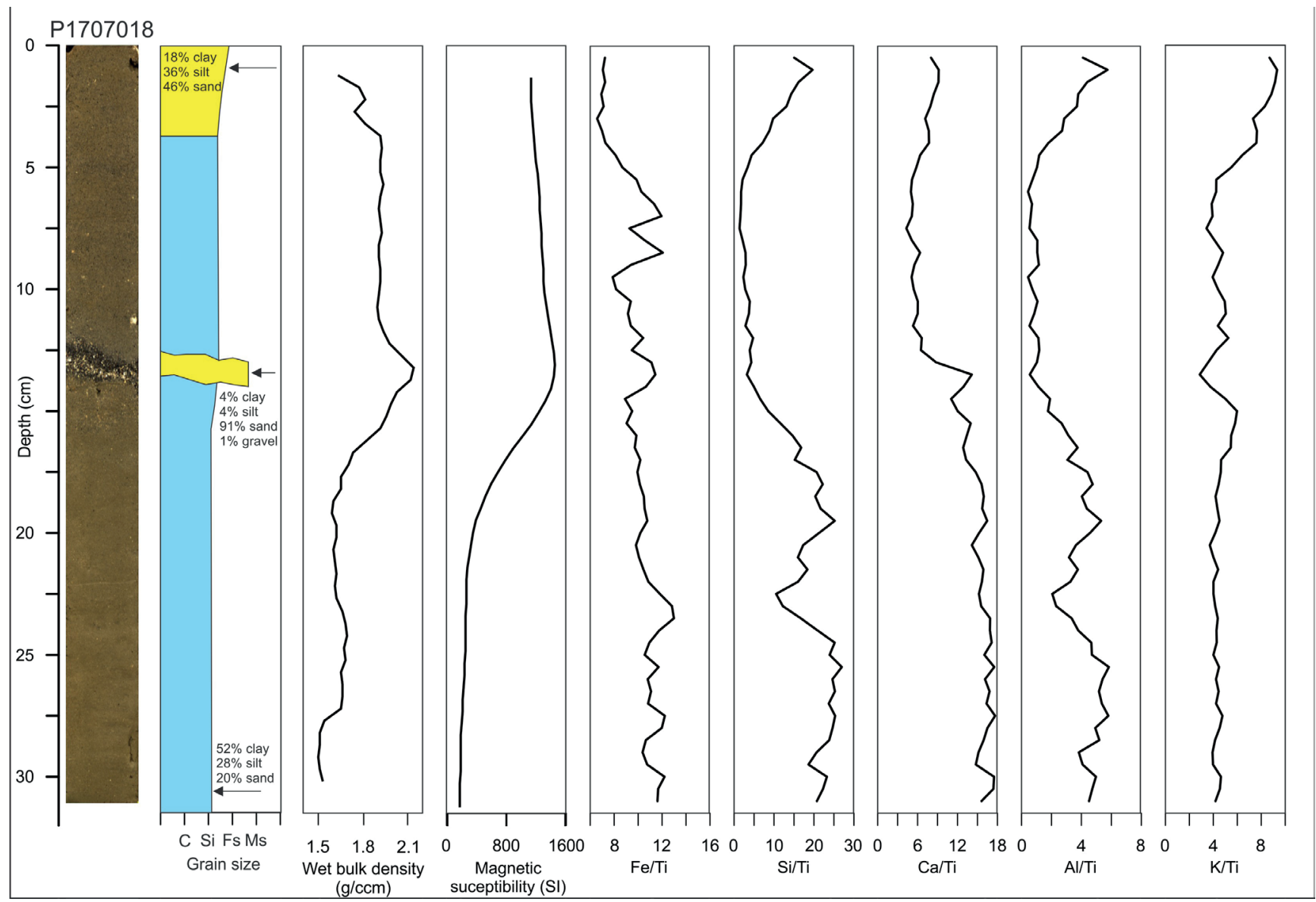

Figure 14. Multisensor core logger (MSCL), XRF and grain-size results for core P1707018. 
Table 3. Mineral composition (\% of total) of natural sediments and tailings in cores P1707010 from Lillebukt and P1707018 from Stjernsundet. Abbreviations: Nph - nepheline, Kfs - K-feldspar, Plg - plagioclase, Amph - amphibole, Px-pyroxene, Qz - quartz, Chl - chlorite, Cal calcite, $\mathrm{Hl}$ - halite, Cat - catapleiite, n.d. - not detected.

\begin{tabular}{lcccccccccccc}
\hline Core: depth $(\mathrm{cm})$ & Sediment & Nph & Kfs & Plg & Mica & Amph & Px & Qz & Chl & Cal & $H l$ & Cat \\
\hline P1707010: $2-4$ & tailing & 21 & 32 & 9 & 4 & 14 & 15 & n.d. & n.d. & 3 & 2 & trace \\
P1707010:14-15 & natural & n.d. & 3 & 28 & 23 & 10 & n.d. & 26 & 8 & trace & 2 & n.d. \\
P1707018: $6-7$ & tailing & 23 & 36 & 14 & 3 & 5 & 4 & 5 & 3 & 5 & 2 & trace \\
P1707018: $22-23$ & natural & n.d. & 10 & 25 & 9 & 11 & 5 & 20 & 5 & 11 & 4 & n.d. \\
\hline
\end{tabular}

\section{Discussion}

\section{Sedimentary processes and depositional environment - Lillebukt}

The low multibeam backscatter intensity in Lillebukt indicates that the seabed here comprises relatively soft and fine-grained sediments. This is confirmed by the grab samples and cores which contain loose, light grey mud and, in the channels, laminae and layers of fine- to medium-grained sand with layers of mud. Fine- to medium-grained sand also occurs along the shore, probably down to wave base at 5-10 m depth. We interpret these sediments as mine tailings.

Fine-grained mine tailings cover the seabed in Lillebukt and the neighbouring bay to the east (e.g., cores P1707007 and P1707008; Fig. 12C) as well as some smaller areas along the shore to the west. As shown in Fig. 2, fine-grained tailings are transported in the water masses by tidal and ocean currents. As the tailings flow into the fjord in the tidal zone, they are sorted according to grain size and density of minerals. Resuspension of the fine-grained part of the tailings probably occurs during periods of rough weather and high waves. Resuspended material may be transported in the water masses further along Stjernsundet before settling again in shallow or deeper water. Berge et al. (1993) estimated that as much as $90 \%$ of the mine tailings were deposited in less than $50 \mathrm{~m}$ water depth. They mapped tailings in the water column up to $3 \mathrm{~km}$ west and $1 \mathrm{~km}$ east of the outlet; $300 \mathrm{~m}$ from the outlet most of the particles were $<0.01$ $\mathrm{mm}$. White 'snow' was found on the seabed along the coast up to $3 \mathrm{~km}$ west and $1 \mathrm{~km}$ east of the outlet. Later investigations by Trannum \& Vögele (2001), Larsen et al. (2004) and Dahl-Hansen et al. (2012) documented an unchanged grain-size distribution of the tailings on the seabed, and a similar distribution of white snow on the seabed along the coast.

It has been shown that the channels in Lillebukt occur in relatively stable positions. A (small) river mouth channel (Fig. 5) probably existed prior to the start of the tailings disposal. This channel, as well as the channel at the tailings outlet and the channel east of the river mouth channel, regularly transport tailings into deeper water in Stjernsundet. Elevated levees are commonly related to channel overflow and deposition of the finer-grained tail from sediment-laden currents (e.g., Bøe et al., 2004a).

Migrating sand waves observed in the time lapse bathymetry and horizontal and cross-laminated sand layers in core P1707010 and grab $\mathrm{P} 1605012$ point towards periodically strong bottom currents with sand transported by density currents/turbidity currents down the channels. Similar processes have been observed in submarine channels in many other places around the world (e.g., Bøe et al., 2004a; Hughes Clarke, 2016). Sand layers alternate with centimetres-thick mud layers, which indicate episodic sand transport. Process water with mine tailings is released continuously without strong pulses. River discharge, on the other hand, is strongly episodic with high discharge during snow melting in the spring and during heavy rainfall. It is likely that density currents through the channels occur during such events. The mud layers in the channels may represent either the fine-grained tail of density currents or fine-grained sediments directly from the tailings outlet, resuspension, loading of ships, etc.

Density currents may also occur during periods of rough weather and high waves. Strong winds and storms blowing towards the north force water towards the beach in Lillebukt, which may cause undercurrents/density currents that transport mine tailings down the channels. The small channels at the sea floor in the eastern part of Lillebukt are possibly scour depressions related to rip currents, where water flows out from the beach during landward-directed southwesterly winds (e.g., Bellec et al., 2010).

Sediment accumulation rates are assumed to be very high at the tailings outlet and in the channel and levee areas, but also outside of the channels, e.g., at the passenger boat quay east of the river mouth where sailing depths are decreasing. Disposed sediments are unstable due to high water contents caused by rapid deposition, but also because of locally steep channel slopes on the levees and channel margins. Slides that transform into density currents are easily triggered in rapidly deposited 
sediments on steep slopes, especially in alternating fine- and coarse-grained sediments with elevated pore pressures (e.g., L'Heureux et al., 2014). High sediment accumulation rates prevent normal consolidation, which may result in increased slope instability and slides, as seen on the southernmost levee in Lillebukt.

Three larger slides within the Lillebukt tailings are known. The first occurred in 1962 outside the administration building and was probably related to road work in combination with deposition of tailings, the second a few hundred metres farther east the night between $29^{\text {th }}$ and $30^{\text {th }}$ October 1978 (Karlsrud \& Aas, 1979), and the latest in the late morning of the $9^{\text {th }}$ October 2017 outside the tailings outlet. The 1978 slide lowered the seafloor 4-7 m over an area $150 \mathrm{~m}$ wide and more than $70 \mathrm{~m}$ seawards. The irregular channel with a slide fan south of the passenger quay (Fig. 5) can possibly be related to the 1978 slide event. The slide coincided with a period of strong wind and high waves that could have triggered the slide. The root cause, however, was interpreted to be high loads of tailings on a soft sediment layer (assumed to be quick clay), not detected by ground investigations. Continuous build-up of tailings would have given increased shear stress in the clay layer, resulting in lower sediment stability (Karlsrud \& Aas, 1979). Other causes for slides can be ship traffic/propeller disturbance, for example during loading of processed ore material, e.g., the partly buried slide escarpment outside of the main quay in the western part of Lillebukt (Fig. 5). The diffuse seismic reflector between the upper and lower units (1-5 m below the seabed) in Lillebukt may represent the seabed prior to the start of tailings disposal in 1961. In the channels, there might have been erosion into older deposits. The XRD data, grain-size data and sediment texture suggest that the sediments in the lower part of core P1707010 from the main channel in Lillebukt are of glaciomarine origin.

Dahl-Hansen et al. (2012) interpreted variations in mud and TOC content in samples from Stjernsundet between 2000 and 2012 to be related to slides from Lillebukt. High mud and low TOC contents in samples were interpreted to indicate that the investigations in 2000 and 2012 were conducted after major slides that led to a higher distal mud content and lowered TOC. Bathymetrical changes in Lillebukt between 2004 and 2012 were also interpreted as indicating slides (Dahl-Hansen et al., 2012).

\section{Sedimentary processes and depositional environments - Stjernsundet}

The Stjernsundet Moraine and the steep fjord slopes along Stjernsundet exhibit medium to high backscatter intensities (Fig. 4), indicating hard and/or coarsegrained sediments (e.g., Bellec et al., 2017). The highest backscatter intensity of the fjord slopes is generally caused by outcropping bedrock. A seabed sediment map compiled by Plassen et al. (2009) shows that the fjord slopes comprise alternating bedrock and sandy gravel, while the Stjernsundet Moraine is covered by sandy gravel, muddy gravel and muddy sand. The Stjernsundet Moraine and till units at the base of the sediment succession were deposited at the end of the last glaciation. Only the upper part of the sediment succession in Stjernsundet has been studied here.

Unit D and underlying strata onlap the Stjernsundet Moraine and are assumed to be of glacimarine origin. Similar, alternating units of stratified and homogeneous sediments occur above glacial deposits in most Norwegian fjords (e.g., Bøe et al., 2003, 2004b; Hansen et al., 2018) where their accumulated thickness may reach hundreds of metres. The hummocky appearance and varying thickness of Unit $\mathrm{C}$ suggests that this is a mass movement deposit.

Unit B is interpreted as homogeneous, fine-grained sediments deposited from suspension in the Holocene. A $1.48 \mathrm{~m}$-long gravity core (T-5; Fig. 1 ) collected from the upper part of the unit in the eastern part of Stjernsundet (483 m water depth) in 1977 has mud throughout (Edvardsen, 1980). Another gravity core (L-1-5; Fig. 1) collected in 1974 close to the southern fjord margin (471 $\mathrm{m}$ water depth) comprises mud, but with some sand in its upper $10-15 \mathrm{~cm}$ (Edvardsen, 1980). A ${ }^{14} \mathrm{C}$ age of 3380 \pm 80 years BP was obtained from foraminifers at $12-16$ $\mathrm{cm}$ depth (Strand, 1979), showing that the sand is not related to the STP. The sand may be derived from the southern fjord slope or reflect erosion and removal of fine sediments in this area. Core P1707020 taken near T-5 (Fig. 1) consists of mud (Fig. 12B) and is interpreted to be representative of Unit B.

Unit $\mathrm{B}$ is absent due to erosion in depressions along the foot of the Stjernsundet Moraine (Fig. 9). The gradual thinning of the unit towards the southern margin of Stjernsundet is also partly related to erosion as shown by internal reflectors being truncated at the seabed (Fig. 10). An originally greater thickness of the unit along the northern margin of Stjernsundet cannot be ruled out, but it appears that much of the thickness change is due to erosion. A $2.4 \mathrm{~m}$-long gravity core (T-4; Fig. 7) was obtained from the eroded area in the deepest trench (471 m water depth) southwest of Lillebukt in 1977 (Edvardsen, 1980). The core consists mainly of mud with sand only in the upper $15-20 \mathrm{~cm}$. The latter may suggest erosion and removal of the fine-grained sediment fraction due to action of bottom currents, possibly tidal currents (e.g., Skarđhamar \& Svendsen, 2005; Skarðhamar et al., 2007). The core location has received very little sand input from the STP. New modelling results confirm strong, ESE-directed bottom currents (average current velocity $0.2 \mathrm{~m} / \mathrm{s}$ ) along the southern margin of Stjernsundet south of Lillebukt (Espenes et al., 2018). 
The pronounced erosion suggests a major change in oceanographic circulation and current regime across the Stjernsundet Moraine and through Stjernsundet. The change was possibly related to changes in relative sea level and circulation changes through the neighbouring sounds Rognsundet and Vargsundet (to the north and east) following isostatic uplift (e.g., Romundset et al., 2011) after the last glaciation. Although the time of onset of erosion is unknown, in the depressions along the foot of the Stjernsundet Moraine and along the southern margin of Stjernsundet, erosion appears to be an ongoing process. Similar erosional features along steep slopes (at the seabed and buried in the stratigraphy) have been observed in many Norwegian fjords (e.g., Bøe et al., 2003; Hansen et al., 2018) and are interpreted to be related to changes in fjord circulation following changes in glacier positions/meltwater discharge, river discharge, and tidal and oceanographic circulation.

The geographical location of Unit A and its wedgeshaped geometry, banked against a steep submarine fjord slope with its apex at a gully in the slope and a pronounced convex topography, has led us to interpret it as a submarine fan deposit (e.g., Normark, 1970; Normark et al., 2009; Covault, 2011; Rise et al., 2013). The medium backscatter intensity of the fan surface indicates relatively coarse and/or compact sediments while two grab samples have documented a high sand content in the fan.

We interpret Unit A as an STP from Sibelco's mine in Lillebukt. It wedges out in all directions away from the northern fjord slope and stops before reaching the trench along the southern margin of Stjernsundet (Figs. 7 \& 10). There is no clear evidence that the wedging out is related to erosion by bottom currents. Thus, the density currents from Lillebukt deposit their sediment load before reaching the trench. The geophysical and geochemical parameters from core logging suggest that core P1707018 (Fig. 14) located close to the margin of the fan (as observed in bathymetry and seismic data; Fig. 7) is influenced by tailings in its uppermost 15-20 $\mathrm{cm}$ (although the uppermost $5 \mathrm{~cm}$ of the core appear less influenced by tailings). The sand interval with many shell fragments at $13 \mathrm{~cm}$ depth probably represents a distal turbidite from Lillebukt. MS reaches $1500 \times 10^{-5} \mathrm{SI}$ at this depth, which is low compared with values from concentrated sand tailings in the upper part of core P1707010 from the channel in Lillebukt $\left(6500 \times 10^{-5} \mathrm{SI}\right.$; Fig. 13). The high sand content in the cores along the fan margin (Figs. $7 \& 12 \mathrm{~A}$ ) and the high MS values in core P1707002 suggest that these deposits are distal tailings. A small amount of fine-grained material in the density currents has been mixed into the water masses and deposited from suspension over a wider area or transported away by ocean currents.

MSCL XRF profiling allows a clear distinction between natural seabed sediments and tailings. Titanium- normalised $\mathrm{Fe}, \mathrm{Si}, \mathrm{Al}$ and $\mathrm{Ca}$ profiles exhibit lower values in the upper (tailings) parts of the studied cores, where magnetic susceptibility values have a clear increasing trend (Figs. 13 \& 14). These changes reflect the mineralogical difference between natural sediments and tailings. The XRD quantifications show that the natural sediments are dominated by quartz, plagioclase and mica whereas tailings have high abundances of potassium feldspar, nepheline and plagioclase, and pyroxene and amphibole in the sand fraction (Table 3 ), reflecting the composition of the mined material. Edvardsen (1980) noted that natural sediments in gravity cores from Stjernsundet have a mineral composition reflecting a significant component from the local mafic and ultramafic bedrock whereas the content of light minerals (quartz, $\mathrm{K}$ - and Na-feldspar) is higher than in the local bedrock, pointing to sediment transport into Stjernsundet by ocean currents and redeposition of Quaternary sediments from the subaerial and subaqueous fjord slopes.

In the period 1962-2018, Sibelco disposed 9 mill. metric tons of tailings in Lillebukt and Stjernsundet while 4.0 mill. tons were disposed between 1998 and 2016 (unpublished data). The WBD of the tailings in core P1707010 from Lillebukt and core P1707018 from the margin of the submarine fan in Stjernsundet is $2.0-2.2 \mathrm{~g} /$ $\mathrm{cm}^{3}$ (Figs. $13 \& 14$ ). MSCL fractional porosity measured for the same intervals is $0.25-0.30 \%$. If we use a wet bulk density of $2.1 \mathrm{~g} / \mathrm{cm}^{2}$ and a fractional porosity of $0.25 \%$, we calculate the mass of tailings deposited between 1998 and 2016 as million $\mathrm{m}^{3}(1.5-2.3$, see Results above ) $\mathrm{x}$ 2.1 tons $/ \mathrm{m}^{3}$ x $0.75=2.4-3.6$ million tons. If we assume, from core descriptions (see above), that on average $0.1 \mathrm{~m}$ of tailings has accumulated in a zone of $500 \mathrm{~m}$ radius surrounding the main fan (mainly post-1998), this gives 1.5 million $\mathrm{m}^{2} \times 0.1 \mathrm{~m} \mathrm{x} 2.1$ tons $/ \mathrm{m}^{3} \times 0.75=$ 0.2 million tons extra. Thus, our calculations (2.6-3.8 mill. tons) fit reasonably well with the numbers from Sibelco for the period 1998-2016. We relate discrepancies mainly to tailings accumulations in Lillebukt waiting to be redistributed by sliding, and fine-grained material transported out of the area by ocean currents. The largest uncertainty in the calculations is related to the quality of the 1998 bathymetry dataset.

\section{Conclusions}

This multidisciplinary study is the first to use a combination of geophysical, geological and geochemical methods to give a detailed picture of the sedimentary processes and distribution of submarine tailings in Lillebukt and Stjernsundet from Sibelco's mine on Stjernøya.

Mine tailings, mainly fine silt to medium sand (0.01- 
$0.5 \mathrm{~mm}$ ), are discharged at the shoreline in the bay of Lillebukt. Fine-grained mine tailings cover the seabed down to $c .100 \mathrm{~m}$ water depth, in the neighbouring bay to the east, as well as in some smaller areas along the shore to the west.

Channels occur in the seabed in Lillebukt. One channel has its starting point at the tailings outlet, another at a river mouth just east of the tailings outlet. These two channels and a third channel meet to form a single channel in around $60 \mathrm{~m}$ water depth. The channels occur in stable positions over time. They are up to $12 \mathrm{~m}$ deep and $180 \mathrm{~m}$ wide in the inner part of the bay, with channel margins sloping up to $35^{\circ}$. Levees, measured from the channel base, are up to $10 \mathrm{~m}$ high in the inner part of the bay and $35 \mathrm{~m}$ high in the outer part of the bay, measured from the channel base to the top of the levee. Small slide scars occur in the levees.

The mine tailings in Lillebukt are transported towards deeper water by density currents and slides. Migrating sand waves observed in time lapse multibeam bathymetry and horizontal and cross-laminated sand layers in grab samples and cores point towards periodically strong traction currents with sand transport down the channels.

MSCL XRF profiling allows a clear distinction between glaciomarine/hemipelagic sediments and tailings. These changes reflect the mineralogical difference between natural sediments and tailings. XRD analyses of a sediment core from the main channel shows only a thin layer of tailings above an erosion surface in glaciomarine clay. This suggests that tailings are regularly transported down the channels by density currents and slides that have eroded into the underlying deposits.

Slides and density currents from Lillebukt continue as turbidity currents down the $45^{\circ}$ fjord slope to deposit their tailings load at a submarine fan extending to $c .463$ $\mathrm{m}$ water depth in Stjernsundet. The submarine fan has a radius of up to $1500 \mathrm{~m}$ and covers an area of c. $1.5 \mathrm{~km}^{2}$. Time lapse bathymetry data show that 2.6-3.8 million tons of tailings accumulated on the fan over the period 1998-2016. Most of the tailings disposed of in that 18 -year period (4 million tons) have accumulated on the submarine fan.

The new data and interpretations document that the influence of Sibelco's STP in the deeper parts of Stjernsundet is limited to the submarine fan and a zone of maximum $500 \mathrm{~m}$ radius outside of the fan. The results of this study show the importance of accurate geological, geophysical and geochemical 4D-mapping to document sedimentary processes and monitor volumetric and lateral changes of STPs and the environmental effects they may cause.
Acknowledgements. This work was performed within the Research Council of Norway project Ny Kunnskap Om Sjødeponi (NYKOS, 236658), cofunded by a consortium of Norwegian Mining Industry Companies including Sibelco Nordic AS. The Norwegian Defence Research Establishment is thanked for permission to use their 1998 multibeam bathymetry data. Two anonymous reviewers provided valuable comments on the manuscript.

\section{References}

Asplin, L., Budgell, P., Ingvaldsen, R., Lien, V., Loeng, H. \& Skagseth, Ø. 2006: Comparison of modelled and measured fluxes at the western Barents Slope. Deliverable D2.6, WP 2, ASOF-N (31.03.06).

Bellec, V.K., Bøe, R., Rise, L., Slagstad, D., Longva, O. \& Dolan, M.F.J. 2010: Rippled scour depressions on continental shelf bank slopes off Nordland and Troms, North Norway. Continental Shelf Research 30, 1056-1069. https://doi.org/10.1016/j.csr.2010.02.006.

Bellec, V.K., Bøe, R., Rise, L., Lepland, A., Thorsnes, T. \& Bjarnadottír, L.R. 2017: Seabed sediments (grain size) of Nordland VI, offshore north Norway. Journal of Maps 13, 608-620. https://doi.org/10.1080/17445647.2017.1348307.

Berge, J., Helland, A., Larsen, L.-H., Moy, F., Sørensen, K. \& Walday, M. 1993: Miljøundersøkelse i Stjernsundet, Finnmark i forbindelse med utslipp av gruveavgang fra North Cape Nefelin AS. Akvaplanniva Report 411.93.372.01.01, 59 pp.

Bøe, R., Rise, L., Blikra, L.H., Longva, O. \& Eide, A. 2003: Holocene mass movements in Trondheimsfjorden, Central Norway. Norwegian Journal of Geology 83, 3-22.

Bøe, R., Bugge, T., Rise, L., Eidnes, G., Eide, A. \& Mauring, E. 2004a: Erosional channel incision and the origin of large sediment waves in Trondheimsfjorden, central Norway. Geo-Marine Letters 24, 225-240. https://doi.org/10.1007/s00367-004-0180-3.

Bøe, R., Longva, O., Lepland, A., Blikra, L.H., Sønstegaard, E., Haflidason, H., Bryn, P. \& Lien, R. 2004b: Postglacial mass movements and their causes in fjords and lakes in western Norway. Norwegian Journal of Geology 84, 35-55.

Covault, J.A. 2011: Submarine Fans and Canyon-Channel Systems: A Review of Processes, Products, and Models. Nature Education Knowledge 3. https://www.nature.com/scitable/knowledge/library/ submarine-fans-and-canyon-channel-systems-a-24178428.

Dahl-Hansen, I.E., Mannvik, H.P. \& Larsen, L.H. 2012: Undersøkelse av miljøtilstanden i Lillebukta og Stjernsund, Finnmark 2012. Akvaplan-niva Report 5463-1,77 pp.

Dearing, J.A. 1994: Environmental Magnetic Susceptibility: Using the Bartington MS2 System. Chi Publishing, 111 pp.

Edvardsen, M.G. 1980: Mineralogiske undersøkelser av grov silt- og sandfraksjonen $i$ marine kvartoravsetninger fra Altadeltaet til ytre Tromsøflaket, Nord-Norge. MSc thesis, University of Tromsø, 167 pp.

Ellis, D.V., Pedersen, T.F., Poling, G.V., Pelletier, C. \& Horne, I. 1995: Review of 23 years of STD: Island Copper Mine, Canada. Marine Georesources and Geotechnology 13, 59-99. https://doi.org/10.1080/10641199509388279.

Espenes, H., Zhou, Q. \& Nøst, O.A. 2018: Spredningsmodellering i Stjernsund: Alternative deponier og ny siktekurve. Akvaplan-niva Report 8827-02,21 pp.

Franks, D.M., Boger, D.V., Côte, C.M. \& Mulligan, D.R. 2011: Sustainable development principles for the disposal of mining and mineral processing wastes. Resource Policy 36, 114-122. https://doi.org/10.1016/j.resourpol.2010.12.001.

Geis, H.P. 1979: Nepheline syenite on Stjernøy, northern Norway. Economic Geology 74, 1286-1295. https://doi.org/10.2113/gsecongeo.74.5.1286.

Geotek 2018: Geotek core analysis systems. https://www.geotek.co.uk/ (accessed 2 November 2018). 
Hansen, L., Bøe, R., Sveian, H. \& Husum, K. 2018: Stratigraphic signatures of glacier activity, marine processes and a possible tsunami in the Leirfjorden fjord-valley system, North Norway. Boreas 47, 792-812. https://doi.org/10.1111/bor.12311.

Heier, K.S. 1961: Layered gabbro, hornblendite, carbonatite and nepheline syenite on Stjernøy, North Norway. Norsk Geologisk Tidsskrift 41, 109-155.

Heier, K.S. 1964: Geochemistry of the nepheline syenite on Stjernøy, North Norway. Norsk Geologisk Tidsskrift 44, 205-216.

Heier, K.S. 1966: Some Crystallo-chemical Relations of Nephelines and Feldspars on Stjernøy, North Norway. Journal of Petrology 7, 95-113. https://doi.org/10.1093/petrology/7.1.95.

Heier, K. \& Taylor, S. 1962: A note on the U, Th and K contents in the nepheline syenite on Stjernøy, north Norway. Norsk Geologisk Tidsskrift 42, 287-292.

Holdridge, D. 1962: A clay mineral from Stjernøy, Norway. Clay Minerals 5, 26-30. https://doi.org/10.1180/claymin.1962.5.27.04.

Hughes Clarke, J.E. 2016: First wide-angle view of channelized turbidity currents links migrating cyclic steps to flow characteristics. Nature Communications 7:11896. https://doi.org/10.1038/ncomms11896.

Ingvaldsen, R., Asplin, L. \& Loeng, H. 2004: The seasonal cycle in the Atlantic transport to the Barents Sea during the years 1977-2001. Continental Shelf Research 24, 1015-1032. https://doi.org/10.1016/j.csr.2004.02.011.

Jensen, H.K.B., Knies, J., Finne, T.E. \& Thorsnes, T. 2007: Mareano 2006 - miljøgeokjemiske resultater fra Tromsøflaket, Ingøy-djupet, Lopphavet og Sørøysundet. Norges geologiske undersøkelse Report 2007.059, 249 pp.

Karlsrud, K. \& Aas, G. 1979: Grunnundersøkelser i forbindelse med utglidningen den 29.10.1978. Norges Geotekniske Institutt Report 78070-1, 12 pp.

Kartverket 2018: Se havnivå. https://kartverket.no/en/sehavniva/ (accessed 2 November 2018).

Knies, J., Köseoğlu, D., Rise, L., Baeten, N., Bellec, V., Bøe, R., Klug, M., Panieri, G., Jernas, P.E. \& Belt, S. 2018: Nordic Seas polynyas and their role in preconditioning marine productivity during the Last Glacial Maximum. Nature Communications 9:3959. https://doi.org/10.1038/s41467-018-06252-8.

Kvassnes, A. \& Iversen, E. 2013: Waste sites from mines in Norwegian Fjords. Mineralproduksjon 3, A27-A38.

Larsen, L.-H., Dahl-Hansen, G., Vögele, B. \& Trannum, H.C. 2004: Miljøundersøkelsen i forbindelse med utslipp av gruveavgang fra North Cape Minerals, Stjernøya, Finnmark, 2004. Akvaplan-niva Report 411.3138, 47 pp.

Lepland, A., Bøe, R., Lepland, A. \& Totland, O. 2009: Tracking the volume and lateral spread of disposed sediments by acoustic methods, Oslo Harbour, Norway. Journal of Environmental Management 90, 3589-3598.

https://doi.org/10.1016/j.jenvman.2009.06.013.

L'Heureux, J.-S., Longva, O., Hansen, L. \& Vanneste, M. 2014: The 1930 Landslide in Orkdalsfjorden: Morphology and Failure Mechanism. In Krastel, S., Behrmann, J.-H., Völker, D., Stipp, M., Berndt, C., Urgeles, R., Chaytor, J., Huhn, K., Strasser, M. \& Harbitz, C.B. (eds.): Submarine Mass Movements and Their Consequences, Advances in Natural and Technological Hazards Research 37, $6^{\text {th }}$ International Symposium, Springer International Publishing, Switzerland, pp. 239-247. https://doi.org/10.1007/978-3-319-00972-8_21.

Li, X. 2013: Alkaline Magmatism, Water-Rock Interaction and Multiple Metamorphism in the Seiland Igneous Province, Northern Norway. $\mathrm{PhD}$ thesis, Fakultät für Chemie, Pharmazie und Geowissenschaften der Albert-Ludwigs-Universität Freiburg im Breisgau, 178 pp.

Mareano 2018: Mareano samler kunnskap om havet. http://www. mareano.no/ (accessed 2 November 2018).

Normark, W.R. 1970: Growth patterns of deep-sea fans. American Association of Petroleum Geologists Bulletin 54, 2170-2195.
Normark, W.R., Piper, D.J.W., Romans, B.W., Covault, J.A., Dartnell, P. \& Sitter, R.W. 2009: Submarine canyon and fan systems of the California continental borderland. Geological Society of America Special Paper 454, 141-168.

Olsen, L. 1998: Løsmasser. In Siedlecka, A., Roberts, D. \& Olsen, L. (eds.): Geologi på Varangerhalvøya: En oversikt med ekskursjonsforslag, Gråsteinen 3, Geological Survey of Norway, Trondheim, pp. 37-44.

Oosterom, M. 1963: The ultramafites and layered gabbro sequences in the granulite facies rocks on Stjernøy (Finnmark, Norway). Leidse Geol Mededelingen 28, 177-296.

Ottesen, D., Dowdeswell, J.A. \& Rise, L. 2005: Submarine landforms and the reconstruction of fast-flowing ice streams within a large Quaternary ice sheet: the 2500-km-long Norwegian-Svalbard margin $\left(57^{\circ}-80^{\circ} \mathrm{N}\right)$. Geological Society of America Bulletin 117, 1033-1050. https://doi.org/10.1130/B25577.1.

Ottesen, D., Stokes, C.R., Rise, L. \& Olsen, L. 2008: Ice-sheet dynamics and ice streaming long the coastal parts of northern Norway. Quaternary Science Reviews 27, 922-940. https://doi.org/10.1016/j.quascirev.2008.01.014.

Pastore Z., Fichler, C. \& McEnroe, S. 2016: The deep crustal structure of the mafic-ultramafic Seiland Igneous Province of Norway from 3-D gravity modelling and geological implications. Geophysical Journal International 207, 1653-1666. https://doi.org/10.1093/gji/ggw362.

Plassen, L., Bøe, R. \& Lepland, A. 2009: Geologi og bunnforhold i Andfjorden og Stjernsund/Sørøysund. Norges geologiske undersøkelse Report 2009.027, 23 pp.

Ramirez-Llodra, E., Trannum, H.C., Evenset, A., Levin, L.A., Andersson, M., Finne, T.E., Hilario, A., Flem, B., Christensen, G., Schaanning, M. \& Vanreusel, A. 2015: Submarine and deepsea mine tailing placements: A review of current practices, environmental issues, natural analogues and knowledge gaps in Norway and internationally. Marine Pollution Bulletin 97, 13-35. https://doi.org/10.1016/j.marpolbul.2015.05.062.

Ramsay, D.M. \& Sturt, B.A. 1970: The emplacement and metamorphism of a synorogenic dyke swarm from Stjernøy, northwest Norway. American Journal of Science 268, 264-286. https://doi.org/10.2475/ajs.268.3.264.

Rise, L. 2013: Leirinnhold i jordarter - en sammenlignende studie med vekt på metodene Coulter Laser 200 og Sedigraph, og forslag til beregning av ekvivalent leirinnhold i prosent. Norges geologiske undersøkelse Report 2013.012,35 pp.

Rise, L., Bøe, R., Riis, F., Bellec, V., Laberg, J.S., Eidvin, T., Elvenes, S. \& Thorsnes, T. 2013: The Lofoten-Vesterålen continental margin, North Norway: Canyons and mass-movement activity. Marine and Petroleum Geology 45, 134-149. https://doi.org/10.1016/j.marpetgeo.2013.04.021.

Roberts, R.J., Corfu, F., Torsvik. T.H., Ashwal, L.D. \& Ramsay, D.M. 2006: Short-lived mafic magmatism at 560-570 Ma in the northern Norwegian Caledonides: $\mathrm{U}-\mathrm{Pb}$ zircon ages from the Seiland Igneous Province. Geological Magazine 143, 887-903.

Robins, B. 1980: The evolution of the Lillebukt alkaline complex, Stjernøy, Norway. Lithos 13, 219-220.

Robins, B. \& Gardner, P.M. 1975: The magmatic evolution of the Seiland Province, and Caledonian plate boundaries in northern Norway. Earth and Planet Science Letters 26, 167-178. https://doi.org/10.1016/0012-821X(75)90084-9.

Robins, B. \& Often, M. 1996: The Seiland Igneous Province, North Norway. Field Trip Guidebook, IGCP project 336. Norges geologiske undersøkelse Report 96.127, 34 pp.

Robins, B. \& Takla, M.A. 1979: Geology and geochemistry of a metamorphosed picrite-ankaramite dyke suite from the Seiland Province, northern Norway. Norsk Geologisk Tidsskrift 59, 67-95.

Romundset, A., Bondevik, S. \& Bennike, O. 2011: Postglacial uplift and relative sea level changes in Finnmark, northern Norway. Quaternary Science Reviews 30, 2398-2421. https://doi.org/10.1016/j.quascirev.2011.06.007. 
Salter, D.L. \& Appleyard, E.C. 1974: An occurrence of vein palygorskite from the nepheline syenite of Lillebukt, Stjernøy, northern Norway. Norsk Geologisk Tidsskrift 54, 329-336.

Sollid, J.L., Andersen, S., Hamre, N., Kjeldsen, O. \& Wilhelmsen, A. 1973: Deglaciation of Finnmark, North Norway. Norsk geografisk Tidsskrift 27, 233-325.

https://doi.org/10.1080/00291951.1973.9728306.

Skarðhamar, J. \& Svendsen, H. 2005: Circulation and shelf-ocean interaction off North Norway. Continental Shelf Research 25, 15411560. https://doi.org/10.1016/j.csr.2005.04.007.

Skarðhamar, J., Slagstad, D. \& Edvardsen, A. 2007: Plankton distributions related to hydrography and circulation dynamics on a narrow continental shelf off Northern Norway. Estuarine, Coastal and Shelf Science 75, 381-392.

https://doi.org/10.1016/j.ecss.2007.05.044.

Strand, J.E. 1979: Paleoklimatiske og stratigrafiske undersøkelser av senkvartore marine sedimenter fra Altafjorden og Tromsøyflaket, Nord-Norge, ved hjelp av bentoniske foraminiferer. MSc thesis, University of Oslo, $107 \mathrm{pp}$.

Trannum, H.C. \& Vögele, B. 2001: Miljøundersøkelser i Stjernsundet, Finnmark, 2000, i forbindelse med utslipp av gruveavgang. Akvaplan-niva Report 411.2031,38 pp.

Vogt, C. 2013: International Assessment of Marine and Riverine Disposal of Mine Tailings. Final Report Adopted by the International Maritime Organization, London Convention/Protocol, 138 pp. 